\title{
DERECHOS Y LIBERTADES EN LA CONSTITUCIÓN DE 1812
}

RAÚL CANOSA USERA 
SUMARIO

1. UNA CONSTITUCIÓN SIN DECLARACIÓN PERO QUE PROCLAMA DERECHOS Y GARANTÍAS. 2. TITULARIDAD DE LOS DERECHOS. 3. LA AUSENCIA DE UNA PROCLAMACIÓN EXPRESA DE LA IGUALDAD ANTE LA LEY, PERO PERVISIÓN DE SUS PRINCIPALES CONSECUENCIAS: IGUALDAD DE DERECHOS, UNIDAD DE FUERO Y UNIDAD DE CÓDIGOS. 4. PROCLAMACIÓN GENERAL DE LA LIBERTAD CIVIL, DE LA PROPIEDAD Y DE LOS DEMÁS DERECHOS LEGÍTIMOS. 5. LOS DERECHOS ESPECÍFICOS DECLARADOS. 5.1. Derechos sustantivos: a) libertad personal. b) Protección de la integridad. c) Inviolabilidad del domicilio. d) La extraña paradoja: libertad de imprenta y proscripción de la libertad religiosa. e) Propiedad. f) Derechos políticos. g) Instrucción pública. h) Legalidad penal. 5.2. Derechos procesales: a) Derecho a juez predeterminado por la ley. b) Derecho a dirimir controversias mediante árbitros. c) Motivación de algunas resoluciones judiciales. d) Derecho a no declarar contra uno mismo. e) Derecho a un proceso público. 6. EL DERECHO DE REPRESENTACIÓN COMO MECANISMO DE DEFENSA DE LA CONSTITUCIÓN Y DE GARANTÍA DE LOS DERECHOS. 7. DEBERES CONSTITUCIONALES. 8. SUSPENSIÓN DE DERECHOS. 9. CONCLUSIÓN. 


\title{
DERECHOS Y LIBERTADES EN LA CONSTITUCIÓN DE 1812
}

\author{
POR \\ RAÚL CANOSA USERA \\ Catedrático de Derecho Constitucional \\ Universidad Complutense
}

\section{UNA CONSTITUCIÓN SIN DECLARACIÓN PERO QUE PROCLAMA DERECHOS Y GARANTÍAS}

La primera cuestión con la que topamos es la recurrente afirmación de que, en la Constitución de 1812, no hay una declaración sistematizada de derechos ${ }^{1}$. En efecto, no la hay ni las Cortes que la aprobaron dictaron una como hizo, lo primero, la Asamblea Nacional francesa - la célebre Declaración de $1789^{2}-$. Es sabido que en el borrador de Constitución se recogían varios preceptos ${ }^{3}$, a la pos-

${ }^{1}$ Como advierte Bartolomé CLAVERO, «no se proclaman con la distinción y compromiso de una declaración», Evolución bistórica del constitucionalismo español, Tecnos, Madrid, 1986, pág. 39. La falta es señalada también por Rafael JIMÉNEZ ASENSIO, Apuntes para una historia del constitucionalsmo español, Zarautz, 1992, pág. 50. En contraste con las declaraciones francesas de 1789, 1791, 1793 y 1795. Las constituciones del Imperio, a partir de la de 1799, no contenían declaraciones. Los textos constitucionales que manejamos se hallan recopilados en versión original y en traducción al español por José Manuel VERA SANTOS, Las Constituciones de Francia, Tirant lo Blanch, Valencia, 2004.

2 Notable diferencia con las Constituciones francesas anteriores que resalta José Luis COMELLAS, «Las Cortes de Cádiz y la Constitución de 1812», en Revistas de Estudios Políticos, núm. 126, 1962, págs. 102 y ss.

3 Se trataba de los atículos 2 a 6 que establecían: 
tre desechados ${ }^{4}$, dedicados a declarar y definir derechos ${ }^{5}$, tal y como hacía su modelo, la Constitución francesa de $1795^{6}$. La ausencia, empero, no puede despacharse con esa mera constatación porque, sin la sistemática adecuada ${ }^{7}$, la Constitución de 1812 proclama numerosos derechos ${ }^{8}$ y procura asegurar su eficacia. Esta preocupación se refleja bien a las claras en el Discurso Preliminar ${ }^{9}$. A la pos-

«Art. 2. Los derechos de los españoles son la libertad, la seguridad, la propiedad y la igualdad.

Art. 3. La libertad consiste en poder hacer todo lo que no perjudica a la sociedad, ni ofende a los derechos de otro.

Art. 4. La seguridad consiste en ser cada individuo protegido por la fuerza pública contra la ofensa que se haga a su persona o sus derechos.

Art. 5. La propiedad es el derecho de gozar y disponer libremente de sus bienes y del fruto de su talento, de su trabajo y de su industria.

Art. 6. La igualdad consiste en que no haya diferencia alguna entre los individuos que componen la nación en el uso y goce de sus derechos». El texto citado se ha extraido de Federico SUÁREZ (coord.), Actas de la Comisión de Constitución (1811-1813), Instituto de Estudios Políticos, Madrid, 1976, pág. 59.

${ }^{4}$ En lo que parece fue una decisión tardía que desactivó la intención reflejada en el proyecto de la comisión, María Cristina DIZ-LOIS, «Estudio Preliminar», en Federico SUÁREZ (Coord.), Actas de la Comisión de Constitución, ob. cit., pág. 58.

${ }^{5}$ Marta LORENTE SARIÑENA ofrece una análisis de tales preceptos que proclamaban la libertad, la seguridad, la propiedad y la igualdad, Las infracciones a la Constitución de 1812, Centro de Estudios Constituionales, Madrid, 1987, pág. 200. También CLAVERO, ob. cit., pág. 59 y José Manuel ROMERO MORENO destaca la similitud de aquel borrador con las Constituciones francesas de 1793 y 1795., Proceso y derechos fundamentales en la España del siglo XIX, Centro de Estudios Constitucionales, Madrid, 1983, pág. 67. En parecido sentido Manuel MARTÍNEZ SOSPEDRA, La Constitución española de 1812 (El constitucionalismo liberal a principios del siglo XIX), Cátedra Fadrique Furio Ceriol, Facultad de Derecho de la Universidad de Valencia, 1978, págs. 51 y ss. También Manuel SEGURA ORTEGA, «Los derechos fundamentales en la Constitucióin de Cádiz de 1812», en Francisco PUY MUÑOZ (Coord.), Los derechos en el consitucionalismo español, Universidade de Santiago de Compostela, 2002, págs. 27 y 28.

6 Artículos 1 a 5; la diferencia estribaba en el orden de los derechos declarados, los mismos, pero el artículo 1 de la Constitución francesa en el siguiente: libertad, igualdad, seguridad y propiedad.

7 Dispersión de los derechos que subraya, entre otros, Jordi SOLÉ TURA y Eliseo AJA, Constituciones y períodos constituyentes en España (1808-1939), Siglo XXI, Madrid, 2009, pág. 16.

${ }^{8}$ Lo que supone un notorio cambio respecto a la situación precedente, JIMÉNEZ ASENSIO, ob. cit., pág. 52. Antonio TORRES DEL MORAL ofrce una lista sistematizada de los derechos proclamados, Constitucionalismos histórico español, Servicio de Publicaciones de la Facultad de Derecho, Universidad Complutense, Madrid, 2010, págs. 53-55. Javier GARCÍA FERNÁNDEZ Y Eduardo ESPÍN TEMPLADO esquematizan los derechos declarados, Esquemas del Constituciomnalismo español, Servicio de Publicaciones de la Facultad de Derecho,Universidad Complutense, Madrid, 1976, págs. 46 y 47.

9 Así lo resalta Luis SÁNCHEZ AGESTA, Historia del constitucionalismo español (1808-1936), Centro de Estudios Constitucionales, Madrid, 1984, págs. 90 y ss. 
tre el definitivo artículo 4 de la Carta gaditana acabaría proclamando «la libertad civil, la propiedad y los demás derechos legítimos de todos los individuos», con una fórmula que, con no ser completa, se emparenta con sus precedentes americanos y franceses, y consagra su personalidad liberal. Es cierto que no proclama, como de sólito hacen las constituciones francesas, la igualdad ante la ley ni reconoce la libertad religiosa —origen del constitucionalismo americano-. Con todo, estas anomalías - formales y sustantivas - no despojan a la Constitución de Cádiz de su aura simbólica genuinamente liberal, incluso democrática.

La segunda cuestión que suscita dudas es el propio nombre que deberíamos emplear para referirnos a los derechos que la Carta de 1812 proclama y a la teoría jurídica que los sustentaba. Como es sabido, el concepto de derecho fundamental es mucho más reciente, en aquella época se hablaba de los derechos del hombre, de los derechos naturales, y de los derechos del ciudadano. No existía tampoco una teoría jurídica en la que apoyar la plasmación constitucional. Se trataba de una experiencia novedosa, salvo en Inglaterra y en especial en los Estados Unidos, mientras que en Europa la base, al carecer de antecedentes jurídicos, era puramente ideológica. Se tenían, pues, los fundamentos filosóficos, pero se carecía de la experiencia de un genuino ordenamiento jurídico de la libertad. El absolutismo había impedido la transformación de lo medieval en un sistema liberal como sucedió en Inglaterra. Así que el reconocimiento jurídico de la libertad fue el hecho revolucionario por excelencia como proclama el artículo segundo de la Declaración de 1789: «El fin de toda asociación política es la conservación de los derechos naturales e imprescriptibles del hombre». Ahora bien ¿cómo conservarlos o en otras palabras, cómo protegerlos? Se trataba de su protección jurídica y los revolucionarios sólo habían dado el primer paso, declaran los derechos en el mismo artículo segundo de la Declaración de 1789: «estos derechos son la libertad, la propiedad, la seguridad y la resistencia a la opresión». La finalidad de la revolución liberal era, pues, la preservación de los derechos naturales que en la teoría jurídica que fue desarrollándose se convirtieron en garantías, apelativo que ilustraba ese afán protector.

En el proceso constituyente gaditano ${ }^{10}$, sin duda materialmente revolucionario y en el que parecieron triunfar los doceañistas —-más radicales-, en el planteamiento formal los más moderados parecen imponerse al presentar la obra

${ }_{10}$ Para indagar en el proceso constituyente es útil el estupendo análisis realizado por COMELLAS, ob. cit., págs. 94 y ss. 
normativa de las Cortes como una actualización — reforma ${ }^{11}$ — de las antiguas Leyes Fundamentales del Reino. Queda esto muy claro en el Discurso Preliminar ${ }^{12}$ y en el breve preámbulo de la Constitución. El resultado acaba siendo más revolucionario que tradicional, pero trufado de apelaciones a lo castizo ${ }^{13}$, a las viejas leyes que habían sido olvidadas por las «prácticas abusivas de la preeminiencia absoluta» ${ }^{14}$ de los reyes. Se ha dicho con razón que las Carta gaditana destaca por su historicismo ${ }^{15}$, al intentar «constitucionalizar la Monarquía católica» ${ }^{16}$.

11 Una reforma constitucional como la calificó Agustín de ARGÜELLES, Examen histórico de la reforma constitucional que bicieron las Cortes Generales y Extrordinarias desde que se instalaron en la isla de León el día 24 de septeimbre de 1810, hasta que cerraron en Cádiz sus sesiones en 14 del propio mes de 1813, Imprenta de Carlos Wood e hijo, 1835. Este intento de presentar la obra de Cadiz como una restuaración de las viejas leyes lo destacan CLAVERO, ob. cit., págs. 35 y ss., SÁNCHEZ AGESTA, Historia..., ob. cit., págs. 45 y ss., Melchor FERNÁNDEZ ALMAGRO, «Del antiguo régimen a las Cortes de Cádiz», en Revista de Estudios Políticos, núm. 126, 1962, págs. 42 y ss., Federico SUÁREZ, «Sobre las raices de las reformas de las Cortes de Cádiz», en Revista de Estudios Políticos, núm. 126, 1962, págs. 31 y ss. CLAVERO destaca la influencia de Jovellanos que entronca con la tradición inglesa, ob. cit., págs. 25 y ss. TORRES DEL MORAL analiza con detalle las numerosas referencias que se hallan en el Discurso Preliminar a las antiguas leyes catellanas, aragonesas o Navarras, al Fuero Juzgo, a las Partidas, a los Ordenamientos Real y de Alcalá y a la Nueva Recopilación, ob. cit., págs. 37 y 38. Marcelino MENÉDEZ PELAYO, sin embargo, niega con rotundidad cualquier conexión de las Cortes de Cádiz con la tradición, Historia de los heterodoxos españoles, Editorial Porrúa, México, 1983, págs. 307 y 308.

12 Se ha destacado con razón la relevancia del Discurso Preliminar para enteder la obra de las Cortes de Cádiz, entre otros, por SÁNCHEZ AGESTA, Historia..., ob. cit., pág. 46, y TORRES DEL MORAL, ob. cit., pág. 31.

${ }^{13}$ Una mezcla de tradición y modelos franceses, según SÁNCHEZ AGESTA, Historia..., ob. cit., págs. 47 y 48. El mismo autor lo recalca con detalle en su Introducción a Agustín de ARGÜELLES, Discurso Preliminar a la Constitución de 1812, Centro de Estudios Constitucionales, Madrid, 1989, refiriéndose a la «raiz tradicional» de la Carta de Cádiz, pág. 137. Una amalgama de principios de origen diverso, en opinión de Francisco FERNÁNDEZ SEGADO, Las Constituciones históricas españolas, Civitas, Madrid, 1986, págs. 66 y ss. O como apunta FERNÁNDEZ ALMAGRO, una tensión de ideas contrapuestas, ob. cit., pág. 12. Luis DIEZ DEL CORRAL explica como hasta los doceañistas invocaron a los teólogos españoles del siglo XVI para justificar en ellos los ideas políticas revolucionarias, El liberalismo doctrinario, Centro de Estudios Constitucionales, Madrid, 1984, págs. 467 y ss.

${ }^{14}$ En palabras de Eduardo GARCÍA DE ENTERRÍA, Prólogo a la Constitución Política de la Monarquía Española, promulgada en Cádiz el 19 de marzo de 1812, Civitas, Madrid, 1999, pág. VIII.

${ }^{15}$ Carlos GARRIGA y Marta LORENTE, Cádiz, 1812. La constitución jurisdiccional, Centro de Estudios Políticos y Constitucionales, Madrid, 2007, pág. 38.

16 Ibid., pág. 21. 
Pero el hecho revolucionario ${ }^{17}$, tras la intervención decisiva de las juntas ${ }^{18}$, se había producido con la atribución a la Nación de la titularidad de la soberanía que las Cortes representaban ${ }^{19}$, aún cuando el Discurso Preliminar trate de justificarse con la apelación a las antiguas leyes españolas ${ }^{20}$. El nuevo sujeto político, la Nación, había irrumpido y ello implicaba despojar al rey de la titularidad de la soberanía para atribuírsela a la Nación dando así lugar a la primera proclamación española del principio constitucional de soberanía nacional ${ }^{21}$ y a la entrada del pueblo en la vida política ${ }^{22}$. Los poderes regios quedaban, desde ese momento, circunscritos a los que la Constitución, expresión de la voluntad soberana de la Nación, les reservaba. Este hecho se asemejó al camino recorrido por la Asamblea Nacional francesa, pero mientras ésta no enmascaró su labor con coartadas tradicionalistas, las Cortes de Cádiz apelaron a las antiguas leyes fundamentales para justificar, disfrazar más bien, su obra revolucionaria y, de paso, eludir la tacha de «francesismo» ${ }^{23}$.

17 Cuya gestación, con su proliferación de dictámenes y decretos, analizan bien Miguel ARTOLA y Rafael FLAQUER MONTESQUI, La Constitución de 1812, Iustel, Madrid, págs. 133 y ss. El vacío de poder facilitó un gobierno de Asamblea, como explica Juan Ignacio MARCUELLO BENEDICTO, «Las Cortes Generales y Extraordinarias: organización y poderes para un gobierno de Asamblea», en Miguel ARTOLA (ed.), Las Cortes de Cádiz, Centro de Estudios Constitucionales, Madrid, 1984, págs. 467 y ss.

18 Acerca de la tarea en cierto modo democratizadora de las juntas, cfr. TORRES DEL MORAL, ob. cit., pág. 45.

19 La proclamación de la soberanía nacional mediante el Decreto I, de 24 de septiembre de 1810, es el hecho verdaderamente revolucionario como señala FERNÁNDEZ SEGADO, ob. cit., págs. 66 y ss. Las Cortes se afriman como poder revolucionario, depositario de la soberanía nacional, SÁNCHEZ AGESTA, Historia..., ob. cit., págs. 52 y 53. En parecido sentido Joaquín TOMÁS VILLARROYA, Breve historia del constitucionalismo español, Centro de Estudios Constitucionales, 1987, pág. 14, y JIMÉNEZ ASENSIO, ob. cit., pág. 49. También ARTOLA y FLAQUER, ob. cit., págs. 302 y 303. El texto de todos los Decretos de las Cortes de Cádiz pueden encontrarse, en su versión original, en Colección de Decretos y Ordenes de las cortes de Cádiz, 2 vols., editados por las Cortes Generales, Madrid, 1987.

${ }^{20}$ Como en la elección del Rey en la monarquía visigoda o en la competencia de las Cortes para otorgar subsidios al Rey o en el uso aragonés según el cual las peticiones elevadas al Rey por las Cortes se convertían casi automáticamente en ley.

${ }^{21}$ FERNÁNDEZ SEGADO, ob. cit., págs. 80 y ss. Aquellas Cortes estamentales en origen se convierten en constituyentes como explica CLAVERO, ob. cit., págs. 33 y ss. También COMELLAS, ob. cit., págs. 86 y ss.

22 COMELLAS, ob. cit., págs. 115 y ss. FERNÁNDEZ SEGADO prefiere hablar de una revolución social protagonizada por la burguesía ilustrada, ob. cit., pág. 69. Revolución de las clases medias la denomina SÁNCHEZ AGESTA, Historia..., ob. cit., pág. 23.

${ }^{23}$ Que se atribuía a modo de anatema entre los constituyentes, SÁNCHEZ AGESTA, Historia..., ob. cit., pág. 45 y FERNÁNDEZ ALMAGRO, ob. cit., págs. 45 y 46. 
La proclamación de la soberanía nacional condujo a la división de poderes ${ }^{24}$ como garantía esencial de la libertad individual, y se reflejó en los debates constituyentes para terminar plasmada en el Discurso preliminar y en la propia Carta. Se tuvo muy presente a Montesquieu, así que la división de poderes rompe con el principio monárquico de un solo poder, de tal suerte que la proclamación de la soberanía nacional permite, tras manifestar ésta su voluntad, distribuir ordenadamente los poderes que se controlan entre sí. Enlazar esta idea con la tradición, en un guiño a la experiencia inglesa y a nebulosos antecedentes patrios, no ocultaba la absoluta novedad que la implantación del principio entrañaba y que con rotundidad defiende el Discurso Preliminar: ${ }^{25}$

«La experiencia de todos los siglos ha demostrado que no puede haber libertad ni seguridad, y por lo mismo justicia ni prosperidad en un Estado en donde el ejercicio de toda la autoridad esté reunido en una sola mano. Su separación es indispensable.»

La explicada ambigüedad en el discurso constituyente (apelaciones constantes a lo tradicional actualizado a la luz de las nuevas teorías políticas) habría de tener consecuencias, también en lo que se refiere a la manera en la que se reconocen los derechos naturales que, en ocasiones y no sin razón, se presentan como formalización de las libertades tradicionales de origen medieval ${ }^{26}$. Su declaración, amén de carecer de la sistemática y de la rotundidad de las declaraciones americanas y francesas, omite el reconocimiento formal de la igualdad ante la ley aunque concrete algunas de sus consecuencias. Falta, pues, rotundidad en la declaración de derechos, agravada por la omisión apuntada y por la negación de la libertad religiosa que más adelante examinaremos. El artículo 4 de la Constitución de Cádiz sólo menciona, y no es poco, la libertad civil, la propiedad y «los demás derechos legítimos de todos los individuos» y va después salpicando el texto con otras libertades y garantías.

A partir de ese momento había que elaborar una teoría jurídica de los derechos y de sus mecanismos de garantía. Comenzaba un camino que aún estamos recorriendo. En ese vacío teórico jurídico, las aportaciones filosóficas o ide-

${ }^{24}$ Cfr. en este sentido SÁNCHEZ AGESTA, Historia..., ob. cit., págs. 81 y ss. FERNÁNDEZ SEGADO, ob. cit., págs. 82 y ss., y TORRES DEL MORAL, ob. cit., pág. 41.

${ }^{25}$ Francisco FERNÁNDEZ SEGADO resalta este pasaje del Discurso y advierte su parecido con el célebre artículo 16 de la Declaración francesa de 1789, ob. cit., pág. 83. Lo que por lo demás defendió el ilustre constituyente Francisco MARTÍNEZ MARINA, Principios naturales de la política y la legislación, Madrid, 1933, pág. 264.

${ }^{26}$ Así lo subrayan TOMÁS VILLARROYA, ob. cit., págs 81 y ss, y TORRES DEL MORAL, ob. cit., pág. 38. 
ológicas no bastaban y por ello no es del todo feliz la proclamación constitucional de los derechos. Si además, como acabó sucediendo en Europa, la constitución, donde los derechos se reconocían, carecía de verdadero valor normativo $^{27}$, entonces los derechos venían debilitados frente al legislador. La disposición que encargaba a la Nación, en realidad a las Cortes, la tarea de proteger los derechos mediante «leyes justas y sabias», acababa dejando en manos del legislador la concreción del alcance de las garantías. Era la ley la que los dotaría de verdadera eficacia, en un esquema relacional constitución-ley que perduraría hasta el siglo XX.

En tales circunstancias, la proclamación constitucional de los derechos no era sino un acto —importantísimo sin duda - de afirmación ideológica, pero abría un campo en el que la consolidación jurídica de los derechos, su conservación y protección, tenía que irse creando en los ordenamientos, acompañada de esa teoría jurídica que los explicase.

El observador actual se halla ahora pertrechado con una teoría jurídica ya consolidada acerca de los derechos y conoce la peripecia histórica de más de dos siglos de desenvolvimiento. Si su análisis pretendiera sorprender en aquellos textos normativos fundacionales los mismos elementos que ahora exigiría al constituyente contemporáneo, concluiría en su insuficiencia y su juicio tendría a la fuerza que ser negativo. El camino es distinto, hay que analizar, primero, la Constitución de Cádiz a la luz de los documentos entonces existentes - muy pocos- y sólo después compararla con el modelo actual para comprobar de dónde partimos y a dónde hemos llegado. En el primer paso advertimos que la Constitución de 1812 es comparable con otras de su tiempo, qué omitió, qué incluyó, en dónde fue más lejos que los textos coetáneos. En el segundo paso sorprenderíamos atisbos, anticipaciones gaditanas, no entrevistos en otros procesos constituyentes. Quizás concluyamos en la posible evolución de aquella Constitución hasta nuestros días, como ocurrió con la todavía vigente Constitución americana de 1787.

\section{TITULARIDAD DE LOS DERECHOS}

La Carta gaditana no emplea la grandilocuente retórica iusnaturalista de los textos americanos o franceses. Ello no es en sí mismo defecto, acaso lo fuera

${ }^{27}$ Que la fuente de los derechos era la ley ha sido reseñado, entre otros por Eduardo GARCÍA DE ENTERRÍA, La lengua de los derechos. La formación del Derecho Público europeo tras la Revolución francesa, Civitas, Madrid, 1994. También por GARRIGA y LORENTE, ob. cit., págs. 377 y ss. 
que la titularidad de los derechos se reservase a los ciudadanos y no sólo la de los derechos políticos. Nada, pues, hay de los «derechos del hombre» franceses ${ }^{28}$, sino una sociedad política, la Nación española, que «es la reunión de todos los españoles de ambos hemisferios» (artículo 1), cuya «libertad civil, propiedad y demás derechos legítimos» que la Nación ha de conservar y proteger» (artículo 4).

Resulta así capital preguntarse a quienes consideraban las Cortes de Cádiz españoles y cómo se perdía o se obtenía tal condición. El constitucionalismo decimonónico se ocupa de este punto ${ }^{29}$, así en la Carta de Cádiz, el artículo 5 (capítulo II del título I, «De los españoles») aclara que son españoles «todos los hombres libres nacidos y avecindados en los dominios de las Españas y los hijos de éstos». La expresión, conectaba con la felicísima del artículo 1: «la Nación española es la reunión de todos los españoles de ambos hemisferios ${ }^{30}$, y traslucía espíritu democrático; además anticipa lo establecido en el artículo 1.2 de la Constitución de 1978, porque funde soberanía nacional y soberanía popular. Pero la Constitución gaditana (artículo 5) se refiere sólo a los hombres, sin que pueda explicarse la omisión de las mujeres como simple resultado de los usos lingüísticos de la época. En efecto, la plenitud de la titularidad de los derechos no alcanzaba a la mujer. En todo caso la Constitución del 12 parece acabar sobre el papel con la injusta distinción entre españoles peninsulares y criollos que tantos perjuicios causaba a los segundos y tantos rencores generaron ${ }^{31}$; esta igualdad ya se había adelantado con el Decreto $\mathrm{V}$, de 15 de octubre de 1810, que la estableció sin equívocos ${ }^{32}$. Para completar lo anterior, el Decreto XXXI, de 9 de febrero de 1811, reconocía a los americanos el derecho de representación igual en Cortes, el de acceso a empleos y la libertad de industria y cultivo.

28 Diferencia con las declaraciones francesas que destaca MARTÍNEZ SOSPEDRA, ob. cit., pág. 306.

29 «Con cierta extensión y prolijidad», apunta Ángel María LÓPEZ y LÓPEZ, «Artículo 11: Nacionalidad», en Oscar ALZAGA VILLAAMIL (dir.), Comentarios a la Constitución española de 1978, Cortes Generales-EDERSA, Madrid, Tomo II, 1997, pág. 129

30 COMELLAS recuerda los enconados debates que generó el concepto de Nación, ob. cit., págs. 97 y ss. Cfr. También Joaquín VARELA SUANZES-CARPENA, La teoría del Estado en los orígenes del constitucionalismo hispánico (las Cortes de Cádiz), Centro de Estudios Constitucionales, Madrid, 1983, págs. 175 y ss.

31 LORENTE, sin embargo, aprecia diferencias en el tratamiento de unos y otros, basándose en los artículos 5 y 18 de la Constitución, ob. cit., pág. 201.

32 Pues disponía que los «dominios españoles en ambos hemisferios forman una sola y única monarquía, una sola nación, y una sola familia, y que por lo mismo los naturales que sean originarios de dichos dominios europeos o ultramarinos son iguales en derechos a los de esta península». 
Si la condición de español se reservaba a los libres, los esclavos no eran titulares de los derechos, como no lo eran, en principio, los extranjeros, pero esto eran libres mientras que los esclavos eran el bien sobre el que un especial derecho de propiedad se ejercía. Tanto el esclavo como el extranjero podían adquirir la condición de español, la ciudadanía, el primero de liberto a ciudadano (artículo 5.4) y el segundo si obtenía la carta de naturaleza (artículo 5.2) tras diez años avecindado en un pueblo de la Monarquía (artículo 5.3).

En el capítulo IV del título II se desgrana la condición de español, su adquisición, su pérdida y su suspensión ${ }^{33}$. Este capítulo parece introducir la distinción entre español y ciudadano español, puesto que si el artículo 4 declaraba españoles a todos los nacidos y avecindados en los dominios de las Españas, el artículo 18 reserva la condición de ciudadanos a «aquellos españoles que por ambas líneas traen su origen de los dominios españoles de ambos hemisferios y están avecindados en cualquier pueblo de esos mismos dominios».

La carta de naturaleza concedida por las Cortes a un extranjero se somete a condición, la primera, «estar casado con española y haber traido en las Españas alguna invención o industria, o adquirido bienes raíces por los que pague contribución directa, o estableciéndose en el comercio con capital propio y considerable a juicio de las mismas Cortes, o hecho servicios señalados en bien y defensa de la Nación» (artículo 20).

El ius solis amparaba la ciudadanía española de los hijos legítimos extranjeros que «no habiendo salido nunca de España sin licencia del gobierno se domicilien en un pueblo de España y ejerzan profesión, oficio o industria útil» (artículo 21). No se niega la condición de españoles a los hijos ilegítimos de padres españoles, pero sí a los ilegítimos de padres extranjeros.

A los españoles habidos y reputados por originarios de África se les abre la puerta a la obtención de la condición de ciudadanos mediante carta concedida por las Cortes, siempre que «se distingan por su talento, aplicación y conducta, con la condición de que sean hijos de legítimo matrimonio de padres ingenuos» (artículo 22). Naturalmente los hijos ilegítimos, en este caso por africanos, son discriminados, aún siendo españoles de origen.

Por último, el artículo 24 enumera las causas de pérdida de la ciudadanía: por adquirirla de otro país, por admitir empleo de otro gobierno y por otras dos causas que sorprenden a la mentalidad moderna: «por sentencia que imponga penas aflictivas o infamantes sino se obtiene rehabilitación», o «por haber residido

33 En un esquema normativo muy similar al empleado por las Constituciones francesas de 1791 (Título II, artículos 2, 3, 4 y 6), 1793 (Del estado de los ciudadanos, artículos 4 a 6) y 1795 (Título II, artículos 8 a 12). 
cinco años consecutivos fuera del territorio español sin comisión o licencia del Gobierno». De la suspensión de derechos nos ocuparemos más adelante.

\section{LA AUSENCIA DE UNA PROCLAMACIÓN EXPRESA DE LA IGUALDAD ANTE LA LEY, PERO PREVISIÓN DE SUS PRINCIPALES CONSECUENCIAS: IGUALDAD DE DERECHOS, UNIDAD DE FUERO Y UNIDAD DE CÓDIGOS}

La igualdad ante la ley es en la revolución burguesa el trasunto jurídico de la igualdad natural que teoriza el iusnaturalismo liberal. La titularidad universal de los derechos sería su consecuencia inmediata ya que la igualdad formal es, sobre todo, igualdad de derechos frente al Estado, como resalta el Discurso Preliminar. La Constitución de Cádiz reconoce numerosos derechos, es decir, formaliza las consecuencias de la igualdad legal; ¿por qué no proclamarla entonces con la misma solemnidad que otras declaraciones coetáneas? Esta fue la intención del borrador de Constitución ${ }^{34}$ que, en efecto, la proclamaba en el artículo 2 e incluso la explicaba, muy didácticamente, en el artículo $6^{35}$. La definitiva omisión ${ }^{36}$ no consagraba por reflejo la desigualdad ${ }^{37}$ porque la formalización de la igualdad, además de la explicada igualdad de derechos, se realiza en los artículos 248 (unidad de fuero salvo para militares — artículo 249- y eclesiásticos —artículo 250-, y unidad de códigos ${ }^{38}$. La unidad de $\operatorname{códigos}^{39}$ se refuerza en el artículo 258: «El código civil y criminal y el de comercio serán unos mismos para toda la Monarquía». Ya antes, en el Decreto LXXXII, de 6 de agosto de 1811, de incorporación de los señoríos jurisdiccionales a la Nación, se suprimían los señoríos «de cualquier clase y condición que sea» y se incorporaban a la Nación. Se trataba de desactivar el clásico esquema absolutista estamental de diversidad de fue-

34 Cuyo valor destaca LORENTE, ob. cit., pág. 200.

35 «La igualdad consiste en que no haya diferencia alguna entre los individuos que componen la nación en el uso y goce de sus derechos»

36 Omisión que comparten los textos constitucionales españoles del siglo XIX, como recuerdan Gustavo SUÁREZ PERTIERRA y Fernando AMÉRIGO, «Artículo 14: Igualdad», en ALAZAGA (dir.), Comentarios a la Constitución..., ob. cit., Tomo II, pág. 254.

37 JIMÉNEZ ASENSIO recuerda que, además de la unidad de fuero, el sufrgio universal compensaba esa omisión que alejaba el texto gaditano de las declaraciones francesas, ob. cit., pág. 51.

38 Esta triple manifestación la analiza SEGURA ORTEGA, ob. cit., págs. 32 y ss.

39 Consecuencia de la igualdad ante la ley, viene autónomamente proclamada por el artículo 85 de la Constitución francesa de 1793. 
ros y ordenaciones sustantivas, de tal suerte que, a pesar de la ausencia de una proclamación de la igualdad en el artículo 4, la obra de las Cortes se enderezó a la consecución de los objetivos que de tal proclamación derivaban. Mejor hubiera sido, desde luego en el plano simbólico, que tal mención se introdujese, como auspiciaba el borrador, al modo de las declaraciones francesas de 1789, $1791^{40}$, 1793 y $1795^{41}$ que emparejaban la igualdad con la libertad, la seguridad y la propiedad. Asimismo las declaraciones americanas hicieron lo propio con un tono distinto y acompañando el reconocimiento de la libertad, de la propiedad y de la seguridad con el goce de la vida y de la búsqueda de la felicidad (artículo I de la Declaración de Virginia).

También falta en la Carta gaditana la declaración del derecho de resistencia a la opresión, imposible en el contexto creado por los constituyentes, de actualización de las antiguas leyes fundamentales del reino y que también se eclipsó en las declaraciones de derechos francesas y sólo la más revolucionaria de 1793 la mantuvo (artículos 11, 33, 34 y 35) ${ }^{42}$. Por mucho que la Cortes estuvieran en verdad protagonizando una obra recolucionaria, ni el contexto español ni la personalidad de la mayoría de los diputados animaban a ser tan claros en las afirmaciones normativas como lo fueron los revolucionarios franceses en su Asamblea. El proceso en ciernes se presentaba como una evolución aunque fuera innegable su carácter al menos parcialmente revolucionario. Reconocer el derecho de resistencia habría equivalido a una confesión.

El Discurso Preliminar trasluce el individualismo propio de las revoluciones liberales y despeja cualquier duda al respecto de lo que se pretendía: «la igualdad legal de los españoles, la imparcial protección que a todos dispensa la Constitución y los medios que sanciona para afianzar la observancia de las leyes». Es decir, el Discurso menciona la «igualdad legal» que luego no se menciona en el texto constitucional donde sí se recogen sus consecuencias: la igualdad de derechos, la unidad de fuero y la unidad de códigos. En todas repara el Discurso cuando sostiene que las leyes «no pueden conocer diferencia ninguna de condiciones ni de clases entre los individuos de este mismo Estado. La ley ha de ser

40 Que en su preámbulo se refería a la igualdad de derechos.

41 El artículo 2 de la Constitución de 1793 declaraba la igualdad en primer lugar, reforzándola con el artículo 3 que establecía: «Todos los hombres son iguales por naturaleza y ante la ley». Por su parte, el artículo primero de la Constitución de 1795 mencionaba la igualdad en segundo lugar, tras la declaración de la libertad.

42 El artículo 33 establecía: «La resistencia a la opresión es la consecuencia de los demás derechos del hombre». El artículo 35 reforzaba lo anterior calificándolo como «el más sagrado de los derechos y el más indispensable de los deberes» cuando el gobierno contraviene los derechos del hombre. 
una para todos; y en su aplicación no debe haber acepción de personas». Más adelante se afirma que la «igualdad de derechos proclamada en la primera parte de la Constitución en favor de los naturales originarios de la monarquía, la uniformidad de principios adoptada en toda la extensión del vasto sistema que se ha propuesto, exigen que el código universal de leyes positivas sea uno mismo para toda la Nación» ${ }^{43}$.

Es más claro el Discurso que la misma Constitución ${ }^{44}$, pues en ésta falta la proclamación general de la igualdad, mientras que en aquel se recoge acompañada de sus consecuencias: mismas leyes procesales y sustantivas para todos los ciudadanos. Ahora bien, más importante que la proclamación solemne de la igualdad es la garantía de sus derivaciones, y en esto no falla la Constitución porque proclama la unidad de fueros que ya el Decreto de 1811 citado imponía, y la unidad de códigos. En suma, las consecuencias principales de la igualdad venían atendidas en la Constitución: la primera, la universalidad de los derechos proclamados, la segunda, la igualdad ante la ley procesal y, la tercera, la igualdad ante la ley sustantiva (unidad de códigos). Las dos últimas sólo podrían cumplirse si el legislador adoptaba esas leyes únicas que a todos se aplicasen.

El Discurso Preliminar trae a colación también lo que ninguna constitución, tampoco las actuales, suele mencionar: la igualdad en la aplicación de la ley, en la que «no debe haber acepción de personas «. Merece destacarse este dato revelador.

A pesar de todo, la suspensión de derechos prevista en los artículos 25 y 26 de la Constitución de Cádiz preveía abrir la puerta ${ }^{45}$ a una diferenciación entre igualdad ante la ley o igualdad civil e igualdad política (ejercicio de derechos políticos que no todos habrían podido disfrutar). Por otro lado, conviene precisar que la igualdad se predica de los ciudadanos españoles, sin atisbo de esa apertura a los derechos del hombre que exhibe la Declaración francesa de 1789. Justo es reconocer aquí que el artículo 14 de la Constitución española de 1978 proclama la igualdad de todos los españoles, excluyendo así a los extranjeros, cuyo régimen se esboza en el artículo 13 constitucional. Como es sabido, la polémica en torno al estatus del extranjero está aún abierta y la protección de sus derechos que ahora deriva no de la preexistencia de derechos naturales, sino de la vigencia de los derechos humanos reconocidos internacionalmente. Han ido decantándose con el

${ }^{43}$ LORENTE apunta que el Discruso Preliminar parece preanunciar la declaración de la igualdad en el texto constitucional, ob. cit., pág. 201.

44 Como destaca FERNÁNDEZ SEGADO, ob. cit., pág. 95.

45 Sostiene LORENTE, ob. cit., pág. 205. 
paso del tiempo cuáles derechos pueden reservarse a los extranjeros. No podemos, pues, reclamar acrónicamente al constituyente de Cádiz que ventilara lo que aún nosotros no hemos resuelto.

\section{PROCLAMACIÓN GENERAL DE LA LIBERTAD CIVIL, DE LA PROPIEDAD Y DE LOS DEMÁS DERECHOS LEGÍTIMOS}

La discusión acerca de este precepto no generó especiales polémicas ${ }^{46}$, tal vez porque, a diferencia de lo que contienen sus equivalentes franceses, omite tanto la mención a la igualdad como a la seguridad, además de eliminar las definiciones de los derechos proclamados que, en la estela de la Constitución de 1795, incluía el proyecto de Constitución.

Porque la Constitución gaditana deseaba presentarse como resultado de una evolución, la literalidad del artículo 4, como casi la de todos los de la Carta, evita los excesos o, si se prefiere, la claridad ideológica de los textos franceses. Ni el Preámbulo de nuestra Constitución se parece al de la Declaración de 1789, ni el artículo 4 gaditano se refiere a los derechos naturales que toda asociación política ha de preservar (artículo segundo de la Declaración de 1789, derechos muy similares a los precedentes americanos, en especial al artículo I de la Declaración de Virginia). Prefiere una expresión menos cargada de ideología, aunque encomiende a la Nación «conservar y proteger por leyes sabias y justas la libertad civil, la propiedad y los derechos legítimos de todos los ciudadanos que la componen». Venían así ligadas la libertad civil y la propiedad en su concepción liberal ${ }^{47}$. Lo determinante empero es que también la Constitución gaditana crea obligaciones específicas para los poderes públicos nacientes, entre ellas y la principal, la de conservar y proteger la libertad civil. Ésta es sin duda una radical innovación porque se incluye entre las tareas del Estado una que había sido por completo desconocida en el absolutismo. Para este la libertad no era un bien jurídico que debiera tutelarse. Así pues en la historia española, por primera vez tiene el Estado la obligación suprema de preservar la libertad, en la línea del artículo 2 de la Declaración de 1789.

No es baladí el apelativo «civil» con el que se acompaña la proclamación de la libertad, pues parece excluirse la libertad política. Los derechos políticos, que luego examinaremos, no se proclaman a favor de todos porque si bien el su-

46 Según SÁNCHEZ AGESTA se aprobó sin pena ni gloria, Historia..., ob. cit., pág. 90. También FERNÁNDEZ SEGADO, ob. cit., pág. 89.

47 Así lo subraya LORENTE, ob. cit., págs. 207 y ss. 
fragio activo se universaliza en apariencia, se restringe el pasivo y se abre la puerta a una mayor reducción del activo, a partir de 1830, a quienes sepan leer y escribir (sufragio capacitario). En resumidas cuentas, lo que en realidad protege el artículo 4 es toda la esfera de la libertad individual, privada, excluyendo los derechos de participación política que merecen en la Constitución un tratamiento diferenciado. En esto la Carta gaditana no se distingue de sus precedentes americanos o franceses que sin calificar de civil la libertad que proclamaron, también regularon por separado la participación política, no siempre de forma democrática. Se abría así la ruta, luego transitada por el liberalismo decimonónico, de universalización de la libertad civil y de restricción de la participación política mediante el sufragio censitario o capacitario.

Se convierte la libertad civil en el bien jurídico más novedoso que trae consigo la Constitución gaditana puesto que la propiedad, con su regulación fragmentaria característica del Antiguo Régimen, no estaba fuera del elenco de bienes jurídicos que el Estado protegía. Pero la libertad que se predica de todos los ciudadanos españoles, constituye rigurosa novedad y merece con justicia ser resaltado ya que se erige en principio cardinal del ordenamiento gaditano ${ }^{48}$. Es verdad que también en este punto el Discurso Preliminar evoca las antiguas leyes de los distintos reinos españoles para cifrar en ellas su fuente de inspiración, libertades antiguas que habían sido, como las facultades de las Cortes, olvidadas por el absolutismo regio.

Además de la genérica libertad y de la propiedad el citado artículo 4 incluye, entre lo que la Nación ha de proteger, «los demás derechos legítimos». Entre estos habría que incluir, desde luego, aquellos que la propia Constitución va después desgranando. Queda la duda de si esta cláusula era de apertura a otros derechos, como la Enmienda IX de la Constitución estadounidense de 1787 o el artículo 29 de la Constitución española de 1869. Es tentador entrever en esta frase una cláusula de apertura que hubiera podido emplearse para dotar de rango constitucional a libertades y derechos que, sin mención expresa en la Constitución, pudieran ser concretados en leyes posteriores. Sea como fuere, todos habrían de ser activados por el legislador mediante «leyes justas y sabias» ${ }^{49}$.

Por lo demás, es muy reveladora esta mención del artículo 4 a las leyes justas y sabias por medio de las cuales la Nación conserva y protege la libertad civil, la propiedad y los demás derechos. Este inciso no puede interpretarse en el sentido

${ }^{48}$ El principio de libertad como lo denominan FERNÁNDEZ SEGADO, ob. cit., pág. 89, y TORRES DEL MORAL, ob. cit., pág. 41.

${ }^{49}$ Lo que, en palabras de CLAVERO, implica un mandato de codificación, ob. cit., pág. 37. 
de que sólo a través de la ley la Nación conserva y protege la libertad, puesto que podría hacerlo de otras muchas maneras, entre otras con la actuación de la policía o de los jueces. De lo que no cabe duda es de que la protección brindada por los demás poderes dependía de la previa regulación legal que los asegurase en su eficacia y los convirtiese en verdaderas garantías. En resumidas cuentas, el artículo 4 resalta la vinculación del legislador a la libertad; en otras palabras, se está poniendo de relieve, de forma muy sugestiva, la relación entre Constitución y ley, entre poder constituyente y poder legislativo ordinario. Ya sabemos, sin embargo, que en Europa no acabaron cuajando las ideas expuestas en la primera hora por Sieyés, de supremacía de la Constitución frente a la ley, y ello acabaría trayendo la nociva consecuencia, entre otras, de que los derechos constitucionalmente reconocidos vinculasen sólo de manera muy laxa al legislador ordinario, convertido por este motivo en su verdadero creador. Porque si no había ley, era imposible el ejercicio de la libertad, por mucho que el derecho de representación, que analizaremos más adelante, pudiera emplearse individualmente para reclamar el respeto de los derechos.

La mención a la ley que hace el artículo 4 podría interpretarse en cualquiera de esas dos maneras expuestas: el legislador está sometido a la libertad o que en realidad es su creador. La mejor interpretación acaso sea la intermedia, entender que el precepto comentado no está reconociendo derechos y libertades concretas sino estableciendo principios inspiradores de la acción del legislador ordinario. A éste le corresponde conservar y garantizar esos principios cuando, mediante la ley, especifique el elenco de derechos y libertades que los ciudadanos van a poder disfrutar. La proclamación genérica de la libertad como bien jurídico que el Estado ha de conservar no implicaría determinación concreta de los contenidos de la libertad que sólo, más tarde, desarrollaría el legislador, al desglosarla en libertades concretas. Al menos parece estar creándose una reserva favor de ley de la materia derechos.

Hay una diferencia sustancial entre las declaraciones francesas y la Constitución gaditana. En las francesas se hizo lo que proponía el proyecto de Constitución gaditano: definir los derechos previamente declarados, también la liber$\operatorname{tad}^{50}$, y acotar así el espacio donde el legislador pudiera adentrarse. Se definía el campo donde pudiera entrar el legislador cuando regulase la libertad, a la que no podría limitar sino para garantizar el ejercicio de la libertad por parte de $\operatorname{todos}^{51}$.

50 Así se procedía en los artículos 4 de la Declaración de 1789, artículo 6 de la Constitución de 1793 y artículo 2 de la de 1795.

51 Artículo 5 de la Declaración de 1789, disposiciones fundamentales de 1791, y artículo 4 de la Constitución de 1793 
Esta concepción se ajustaba perfectamente con el carácter en principio ilimitado de los derechos naturales. Puesto que la sociedad y el Estado sólo son legítimos si preservan, en lo posible, íntegra la libertad natural, toda limitación legalmente establecida que vaya más allá de esa finalidad sería ilegítima. Pues bien esta limitación de la capacidad limitadora del legislador no la hallamos en la Constitución gaditana, únicamente el mandato de que las leyes sean «justas y sabias». En realidad lo que la moderna teoría constitucional reclama es que el contenido de las leyes sea conforme al contenido de la constitución, pero esto es mucho pedir al constituyente de hace doscientos años.

\section{LOS DERECHOS ESPECÍFICOS DECLARADOS}

Como el constituyente prefirió dispersar el reconocimiento de derechos a lo largo de todo el texto y no concentrarlos en una sistemática declaración ${ }^{52}$, la ubicación de cada uno de ellos tenía que depender del ámbito material donde cada derecho fuera a ser ejercitado, así que no sorprende que varios de los derechos sustantivos se pongan en conexión con el funcionamiento de los tribunales ${ }^{53}$ porque, sin ser derechos procesales, su potencial lesión sólo podría acontecer en el marco de investigaciones que hubieran de ventilar los tribunales de justicia ${ }^{54}$. Por su parte, la ubicación de los derechos genuinamente procesales en el título dedicado a la Administración de Justicia quedaba plenamente justificada. Menos clara parece la situación de la libertad de imprenta reconocida en la parte dedicada a la instrucción. Veamos a continuación cada caso.

\subsection{Derechos sustantivos}

Son muchos los derechos sustantivos en la Constitución de 1812, pero no todos los que proclaman otras declaraciones, en especial, las francesas. Por supuesto falta el derecho a poseer y llevar armas que el artículo VII del Bill of Rights de 1689 reconocía a los protestantes y a todos la enmienda segunda de la Constitución de 1787. Pero la ausencia más clamorosa es la de la libertad religiosa que no falta en ningún documento constitucional americano o francés. Tampoco

52 Esto, lejos de ser defecto, evitaba los vicios idealistas de las declaraciones francesas, ROMERO, ob. cit., págs. 67 y ss.

${ }^{53}$ Constituyendo verdaderas garantías, ROMERO, ob. cit., pág. 87.

${ }^{54}$ ROMERO destaca y elogia esta vertiente jurisdiccional, ob. cit., págs. 77 y ss. 
aparece en la Carta gaditana el derecho a la seguridad ${ }^{55}$ cuyo contenido resulta incierto a pesar de las definiciones francesas.

Por las razones ya explicadas, tampoco en la Constitución de Cádiz asoma el derecho de resistencia a la opresión ya expreso en textos americanos y nítido en la Declaración de 1789 y en la Constitución de 1793. Ni el derecho de petición, como veremos al tratar el derecho de representación. Ni el derecho de reunión ${ }^{56}$, sólo contemplado en la Constitución francesa de 1793 (artículo 122).

Se omite en Cádiz el muy francés derecho a participar en la formación de la ley (artículos 6 de la Declaración de 1789, 29 de la Constitución de 17983 y 20 de la de 1795), así como el derecho a contratar servicios pero no enajenar la propia persona (artículos 18 de la Constitución de 1793 y 15 de la Carta de 1795).

Con todas estas omisiones de las cuales la única verdaderamente clamorosa, por incoherente con los principios fundamentales del liberalismo, es la de la libertad religiosa, las proclamaciones gaditanas, sin la sistemática equiparable, pueden en lo esencial parangonarse a las foráneas.

\section{a) Libertad personal}

La libertad civil genéricamente evocada en el artículo 4 de la Carta magna gaditana, se reserva en principio a los españoles que sean libres y por ello ostenten la condición de ciudadanos que se desgrana en los artículos 18 y siguientes (capítulo IV, título II). El artículo 5, ya antes, dispone, como hemos apuntado páginas atrás, que «son españoles todos los hombres libres nacidos y avecindados en los dominios de las Españas y los hijos de estos». Había, en consecuencia, personas nacidas en los dominios españoles que no ostentaban la cualidad de ciudadanos porque penaban bajo el régimen de esclavitud aunque pudieran librarse de ella (artículo 5.4). La libertad personal todavía no se contemplaba ni en España ni en otras partes como consustancial al ser humano que podía nacer esclavo o caer en esta vil condición. Muchos años habrían de pasar para que se aboliese la esclavitud de los dominios españoles, así que la libertad personal aún no era en puridad un derecho universal, como no lo era ninguno de los proclamados en el primer liberalismo; sólo los hombres libres gozaban de todas las garantías.

55 Artículos I de la Declaración de Virginia y artículos 2 de la Declaración francesa de 1789, 2 de la Constitución de 1793 y 1 de la de 1795.

56 Que solo aparecería en la Constitución de 1869, como recuerda Ramón SORIANO DÍAZ, «Artículo 21: Derecho de reunión», en ALZAGA (dir.), Comentarios..., ob. cit., Tomo II, pág. 581. 
En la Carta de Cádiz no hayamos las felices y muy doctorales aseveraciones de las declaraciones francesas que ya analizamos en el epígrafe anterior. Lo que en Cádiz se asegura es la libertad del ciudadano frente a detenciones arbitrarias ${ }^{57}$ : sólo podía privarse de libertad tras informar sumariamente al detenido del hecho presuntamente cometido y si este se hallaba castigado con pena corporal; además la detención debía ser decretada con auto del juez que se comunicará al preso (artículo 287). Así que el detenido tenía derecho a ser informado de los hechos que se le imputaban y que estos fueran de gravedad tal que llevase aparejada la sanción de prisión, además debía ser decidida por el juez mediante auto. Sólo cabía la autoría judicial para adoptar esta restricción de la libertad, salvo en caso de flagrante delito $^{58}$ (artículo 292) pero con obligación de que el detenido fuera presentado ante el juez como mucho en plazo de 24 horas (artículo 290). En este supuesto sólo el juez podría, mediante auto además motivado, ordenar el ingreso en prisión.

En rigor, no se recoge el bábeas corpus ${ }^{59}$ frente a detenciones ilegales al modo anglosajón, lo que se pretende es proscribirlas dejándolas fuera de la legalidad constitucional, que entroniza la función del juez de manera más enérgica que las declaraciones francesas.

Como sucedía con la propiedad, también respecto de la libertad personal, el artículo 172, al delimitar las restricciones de la autoridad del Rey ${ }^{60}$, le prohíbe (apartado undécimo) «... privar a ningún individuo de su libertad ni imponerle por sí pena alguna». A continuación se hace recaer en el secretario de Despacho que firme la orden y en el juez que la ejecute, la responsabilidad de tal exceso por lo cual serán castigados «como reos de atentado contra la libertad individual». Se perfila incluso un tipo delictivo, de atentado contra la libertad individual, para erradicar una práctica, común en el absolutismo regio, la privación de libertad por orden del Rey.

El citado precepto contiene el supuesto habilitante para que el Rey expida órdenes de privación de libertad con dos limitaciones, una sustantiva y otra procesal, la primera, que tales órdenes sólo podían dictarse «en el caso de que el bien y la seguridad del Estado exijan el arresto de alguna persona». Por muy lábil que

57 En otras palabra, la inviolabilidad personal, ROMERO, ob. cit., pág. 287, o la seguridad personal, según FERNÁNDEZ SEGADO, ob. cit., pág. 89, garantía que ya habían establecido las declaraciones francesas: artículo 7 de la de 1789, artículos 10 y ss. del Capítulo V, Título I, de la Constitución de 1791, artículo 10 del preámbulo de la Constitución de 1793 y artículo 8 de la Constitución de 1795.

58 ROMERO destaca el precedente de la Partidas, ob. cit., pág. 87.

59 Aunque así lo denomine ROMERO que recuerda el precedente de la Partidas, ob. cit., págs. 84 y ss.

${ }^{60}$ Bien explicado por ROMERO, ob. cit., pág. 80. 
sea este texto, necesitado de un desarrollo normativo posterior, tiene por finalidad acotar las facultades extraordinarias que contempla, como excepción a la restricción general. El Rey no puede ordenar detenciones, sino sólo cuando se halle en riesgo el bien y la seguridad de Estado, así que una interpretación extensiva de la excepción dejaría sin efecto la prohibición general y debía desecharse.

La limitación procesal deriva de la exigencia de presentar al órgano judicial competente a la persona del arrestado, fijando un plazo de sólo 24 horas. Llama la atención lo breve plazo, pues en la Constitución de 1978 se extiende hasta las 72 horas.

De todo lo anterior se infiere, primero, el derecho a no ser privado de libertad por orden regía salvo en caso de riesgo para el bien y seguridad del Estado y, segundo, el derecho a ser puesto disposición del juez competente en un plazo máximo de 24 horas.

Al trazar los contornos constitucionales de la detención, el constituyente de Cádiz introduce una garantía complementaria a la contenida en el artículo 287. Si en este precepto se determinaba que sólo era posible la detención si el hecho que la justifica estaba sancionado con pena corporal, el artículo 296 disponía que si no se daba este supuesto, al detenido «se le pondrá en libertad dando fianza».

b) Protección de la integridad

Todavía en la actualidad se debaten los contornos del derecho a la integridad personal, no siempre así reconocido. Hay empero acuerdo en la proscripción de la tortura y de los tratos inhumanos o degradantes. La primera manifestación de esta prohibición nos la ofrecen los textos anglosajones ${ }^{61}$. La ilustración y su trasunto político, el liberalismo, habían hecho bandera de ese humanitarismo que consideraba ultrajante de la dignidad humana lo que desde antiguo había sido contemplado con naturalidad: el empleo de la tortura en los procesos penales. Fue el primer paso para la protección de la integridad, proscribiendo sus vulneraciones más graves que hasta ese momento practicaba el Estado para la obtención de confesiones.

El liberalismo continental incluye la prohibición de todo rigor innecesario ${ }^{62}$ en sus declaraciones de derechos (declaración francesa de 1789 y sucesivas cons-

${ }^{61}$ Artículo X del Bill of Rights, de 1689 y, casi con las mismas palabras, las declaraciones americanas (Artículo IX de la Declaración de Virginia, de 12 de junio de 1776, y enmienda octava a la Constitución de 1787.

62 Así el artículo 9 de la Declaración de 1789 establecía que «todo rigor que no sea necesario para mantenerlo retenido debe ser severamente reprimido por la ley». En esta línea y extendiéndola a la detención, los artículo 13 de la constitución de 1793 y 232 de la Carta de 1795. 
tituciones). Precedida por el Decreto LXI, de 22 de abril de 1811, de abolición de tortura y de los apremios y prohibición de otras prácticas aflictivas, que del modo más enérgico había proscrito este tipo de malos tratos, y por el Decreto CCXXVIII, de 24 de enero de 1812 (abolición de la pena de horca y su sustitución por el garrote ${ }^{63}$ ), la Carta de Cádiz no es la excepción y su artículo $302^{64}$ de modo lapidario y más enérgico y claro que en las declaraciones francesas, dispone: «No se usará nunca del tormento ni de los apremios». Prohibición sin excepciones que genera un derecho absoluto a no sufrir tortura ni apremio. Lo que para nosotros es indiscutible significó en su época avance extraordinario ya que si, por un lado, nadie podía ser privado de libertad, sino cuando el hecho presuntamente cometido fuera merecedor de pena corporal, durante esa privación de libertad venía prohibida la tortura como método de investigación criminal. Se trataba de un cambio radical en el sistema penal cuyo rasgo esencial, durtante el antiguo régimen, era precisamente el empleo del tormento ${ }^{65}$. El Discurso Preliminar también en este punto presenta la obra de las Cortes como recuperación de antiguos usos españoles y, en concreto, la tradicional prohibición del tormento que fue regla en Aragón.

También se limita el uso de la fuerza (artículo 289) «para asegurar la persona», pero sólo «cuando hubiere resistencia o se temiere la fuga». Esta cautela acaba restringiendo el uso de la fuerza física por parte del Estado. Queda proscripto en la investigación criminal el tormento y los apremios y sólo puede emplearse la fuerza física en la detención de las personas si oponen resistencia o se teme la fuga.

c) Inviolabilidad de domicilio

Uno de los derechos clásicos que tiene expreso reconocimiento en la Constitución de Cádiz es la inviolabilidad de domicilio ${ }^{66}$, recogida en el artículo 306 que establece: «No podrá ser allanada la casa de ningún español, sino en los casos que determine la ley para el buen orden y seguridad del Estado». Esta proclamación que en las declaraciones francesas no se realiza junto con los demás derechos sino relegándola a otras partes del texto normativo,

${ }^{63}$ La horca, considera el Decreto, es «espectáculo demasiado repugnante a la humanidad y al carácter generoso de la nación española».

${ }^{64}$ Según ROMERO, la regualción gaditana es mejor que las francesas que la precedieron, ob. cit., pág. 89.

65 SEGURA ORTEGA, ob. cit., pág. 36.

${ }^{66}$ Cfr. FERNÁNDEZ SEGADO, ob. cit., pág. 90. 
rompe con los usos absolutistas y como otras se encuentra en el título V, dedicado a los tribunales, y en concreto en el capítulo III, «De la administración de justicia de lo criminal». La literalidad del precepto, como se ve, es similar a la de la vigente Constitución española de $1978^{67}$, y es la propia de una garantía. Así mientras que en él texto actual se afirma que «el domicilio es inviolable...», el precepto gaditano prohíbe el allanamiento. En ambos casos hay posibilidad de que la entrada se produzca, si bien el texto de 1812 se remitía a la ley que debía concretar «el buen orden y seguridad del Estado» que podrían justificar el allanamiento domiciliario. En este punto el texto de 1978 es mucho más moderno pues precisa exhaustivamente los supuestos de entrada o registro. Sin embargo la Carta gaditana se refiere a una finalidad del allanamiento ausente en la Constitución de 1978: la de servir al «buen orden y seguridad del Estado». Un interpretación estricta de esta cautela descartaría toda entrada en domicilio particular para hallar pruebas de la comisión de un delito donde no se pusiese en peligro el buen orden y seguridad del Estado. Parece postura exagerada y garantía exorbitante. Si hubiera que optar por la interpretación más laxa el buen orden y seguridad de Estado equivaldría a orden público y cualquier delito lo pondría en jaque, y su indagación justificaría el allanamiento ${ }^{68}$.

Amén de la indeterminación explicada que contrasta con la relativa mayor precisión de las declaraciones francesas ${ }^{69}$, también cabe achacar al artículo 306 no reparar en el papel de los jueces a la hora de determinar la entrada en domicilio, ni el artículo 172 proscribe expresamente al Rey ordenarla. No obstante, la remisión a la ley, también contenida en el texto francés, es garantía suficiente, puesto que la regla constitucional es clara: prohíbe el allanamiento y las excepciones sólo pueden ser las legales y la ley a las Cortes corresponde aprobarla. Con todo, el reconocimiento de este derecho supone un indudable avance respecto de la situación anterior, dominada por la pura arbitrariedad.

${ }^{67} \mathrm{Y}$ no muy distinta de las declaraciones francesas de 1789, 1793 y 1795, ROMERO, ob. cit., pág. 91.

68 ROMERO pone el acento en la interpretación de esta cláusula cuyo alcance era necesario fijar, ob. cit., pág. 92.

69 Así, el artículo 9 del Título IV de la Constitución de 1791 dispone dos supuestos: ejecución de un mandamiento para mantener el orden y la justicia y en los casos previstos por la ley. Ambos supuestos, como se ve, son muy generales. Más preciso, sin duda, es el artículo 359 de la Constitución de 1795 que prescribe los requisitos de entrada: «en virtud de una ley y para la persona o el objeto expresamente designado en el acto que ordene la visita». 
d) La extraña paradoja: libertad de imprenta y proscripción de la libertad religiosa

Una de las rarezas de la Constitución de Cádiz es la proclamación de la libertad de imprenta ${ }^{70} \mathrm{y}$, en implícita consecuencia, la de la libertad ideológica, al mismo tiempo que se niega la libertad religiosa y se establece la confesionalidad del Estado ${ }^{71}$. En efecto, si por un lado el artículo 12 prohíbe el ejercicio de cualquier religión, salvo la católica ${ }^{72}$, a cuya salvaguarda está llamada a Nación, el artículo 371, curiosa y significativamente ubicado en el Título IX ( «De la instrucción pública» $)^{73}$, reconoce a todos los españoles «libertad de escribir, imprimir y publicar sus ideas políticas sin necesidad de licencia, revisión, aprobación alguna anterior a la publicación, bajo las restricciones y responsabilidades ${ }^{74}$ que establezcan las leyes». Tal libertad había sido profusamente ejercida al amparo del Decreto IX, de 10 de noviembre de 1810, de libertad política de imprenta, que anticipó la posterior redacción constitucional.

Había entonces que hacer un delicado ejercicio de deslinde ${ }^{75}$ entre libertad de pensamiento religioso y libertad de pensamiento político, amparada esta última por el artículo 371 y proscrita aquella por el ya citado artículo 12. Los acontecimientos de entonces así lo demuestran, pues el libérrimo ejercicio de la libertad de imprenta suscitó airadas protestas de los sectores más integristas que deseaban

70 En opinión de ROMERO, uno de los escasos derechos materiales reconocidos en Cádiz, ob. cit., pág. 73. Proclamación que se adelantó con el Decreto IX, de 16 de noviembre de 1810, como recuerdan JIMÉNEZ ASENSIO, ob. cit., pág. 51, y explica FERNÁNDEZ SEGADO, ob. cit., págs. 68 y ss. Así se facilitó su ejercicio durante el período constituyente como destaca Emilio LA PARRA LÓPEZ, La libertad de prensa en las Cortes de Cádiz, Nau, D.L., Valencia, 1984, págs. 12 y ss.

${ }^{71}$ Como destacan entre otros CLAVERO, ob. cit., pág. 41, SÁNCHEZ AGESTA, Historia..., ob. cit., pág. 93 y ss., o FERNÁNDEZ SEGADO, ob. cit., pág. 201 y 202. Confesionalidad del Estado e intolerancia religiosa van así de la mano, SEGURA ORTEGA, ob. cit., págs. 23 y ss. José María BENEYTO PÉREZ ofrece un análisis que compara la Carta de Cádiz con las Constituciones posteriores, «Artículo 16: Libertad ideológica y religiosa», en ALZAGA (dir.), Comentarios a la Constitución española..., ob. cit., Tomo II, pág. 310.

72 Convirtiéndola por reflejo en un deber, ROMERO, ob. cit., pág. 76. Aunque no se recogieran todas las aspiraciones de los contituyentes ultrarealistas, MARTÍNEZ SOSPEDRA, ob. cit., págs. 316 y ss.

73 Así lo destaca ROMERO, ob. cit., pág. 73.

74 ROMERO compara esa pobible exigencia de responsabilidades y de imponer retricciones a la luz del artículo 353 de la Constitución francesa de 1795 en el que el precepto gaditano se inspira, ob. cit., pág. 73.

${ }^{75}$ De cuya dificultad ya alertaron entonces algunos diputados y resalta MENÉNDEZ PElAYO, ob. cit., págs. 279 y ss. 
acotar esta libertad que consideraban exorbitante en sus manifestaciones concretas y poco respetuosas con la religión. El régimen jurídico era muy distinto en cada caso, pues para esta última existía una censura mientas que se proscribía para la libertad de imprenta. Los constituyentes advirtieron de la necesidad de una opinión pública libre fundada sobre el comercio de las ideas políticas que contribuyera a formarla. De este comercio de las ideas excluían, sin embargo, las religiosas, por entender que la religión católica, «única verdadera», era la propia de la Nación española. Quedaba así proclamado el principio de unidad religio$\mathrm{sa}^{76}$, bien es cierto que con tono regalista que no ha pasado desapercibido ${ }^{77}$.

Tan importante debió parecer a los padres de la Constitución la tarea de proteger la libertad de imprenta ${ }^{78}$ que a la genérica misión encomendada a la Nación por el artículo 4 de «conservar y proteger la libertad civil y la propiedad mediante leyes sabias y justas», el artículo 131, vigesimocuarta, concreta como facultad de las Cortes la de "proteger la libertad política de imprenta». Quedaba así clara la especificación política de esta libertad, sin amparo para una genuina libertad de pensamiento y de imprenta asociada a cualquier idea. Había de ser en el terreno práctico que por desgracia no tuvo tanto recorrido, donde se acotara el margen reservado a las ideas religiosas, incuestionables, y al resto de las ideas que sí podían ser objeto de controversia pública. Mientras que en el ámbito anglosajón y mucho después también en el francés, la libertad religiosa, y en el caso galo, la clara animadversión hacia la Iglesia católica, originaron o sirvieron de fundamento a la libertad ideológica en general y política en particular, el catolicismo de la mayoría de los constituyentes gaditanos impuso esa extraña, a ojos actuales, combinación entre Estado confesional, con proscripción de otras religiones, y libertad de imprenta de ideas políticas.

76 Así lo resaltan SÁNCHEZ AGESTA, Historia..., ob. cit., págs. 93 y ss., TORRES DEL MORAL, ob. cit., págs. 43 y ss. FERNÁNDEZ ALMAGRO apunta, empero, que su destino era ser eludido por los acontecimientos futuros, ob. cit., pág. 101. FERNÁNDEZ SEGADO discrepa de esta opinión, ob. cit., pág. 94. Lo que se manifiesta a la postre con el Decreto CCXXIII, de 22 de febrero de 1813 , de abolición de la Inquisición y establecimiento de los tribunales protectores de la fe.

77 Entre otros por SÁNCHEZ AGESTA, Historia..., ob. cit., pág. 95, y FERNÁNDEZ SEGADO, ob. cit., pág. 95.

${ }^{78} \mathrm{Su}$ proclamación en 1810 y los debates constituyentes ilustran acerca de esa importancia; se veía claro que era esencial para crear un régimen de opinión pública, como destacan SÁNCHEZ AGESTA, Historia..., ob. cit., págs. 89 y ss. El mismo SÁNCHEZ AGESTA en su introducción al Discurso Preliminar de Argüelles ya lo había apuntado, ob. cit., págs. 46 y ss. FERNÁNDEZ SEGADO, ob. cit., pág. 91, Y COMELLAS, ob. cit., págs. 91 y ss. ROMERO subraya su función de freno al gobierno, ob. cit., pág. 79. El más famoso derecho proclamado en la Carta de Cádiz, apunta SEGURA ORTEGA, ob. cit., pág. 30. 
Sobre éstas pesaban de modo indeterminado las limitaciones que se infiriesen del catolicismo oficial.

En la misma fórmula de juramento del Rey (artículo 173) se refleja la contradicción apuntada, pues lo primero que contiene la fórmula es la evocación a la defensa y conservación de la religión católica «sin permitir otra alguna en el Reino», para después prometer respeto a la «libertad política de la Nación y la de cada individuo».

En este punto la Carta gaditana se aparta de los precedentes franceses y americanos que con rotundidad proclaman la libertad religiosa y la neutralidad del Estado en este terreno. Así, la primera enmienda a la Constitución de 1787 prohíbe al Congreso establecer o prohibir el libre ejercicio de cualquier religión para, a renglón seguido, proteger la libertad de palabra y de imprenta. Antes el artículo 16 de la Declaración de Virginia había ya proclamado la libertad religiosa, y su artículo 12 la libertad de imprenta.

Por su parte el artículo 10 de la Declaración de 1789 proclama la libertad de opinión, y expresamente de opiniones religiosas, y el artículo 11 la libre comunicación de pensamientos y opiniones y la libertad, a la postre instrumental, de imprenta. Con este punto de partida, la Constitución de 1791, en sus Disposiciones fundamentales, salvaguarda estas libertades y proscribe la censura previa, para después en su artículo 17 del Capítulo V prohibir toda investigación o persecución por escritos publicados, salvo en los casos tasados.

La misma Constitución de 1791 contiene sin embargo prescripciones que parecen limitar la libertad religiosa en la esfera de la hoy llamada libertad de autoorganización de cada grupo religioso; en efecto, una de las Disposiciones fundamentales establecía que «los ciudadanos tienen derecho a elegir o a escoger a los ministros de sus cultos». Por añadidura nacionaliza los bienes destinados al culto. Estas disposiciones traslucen el enfrentamiento de los revolucionarios con la Iglesia católica y diferencian el contexto revolucionario francés del español, y ello a pesar de que en España predominaron las posiciones jansenistas que fomentaban un regalismo que en grado superlativo materializa la Constitución de 1791. En definitiva, las disposiciones constitucionales francesas no son ateas pues sus preámbulos $(1789,1793$ y 1795) invocan al ser supremo, pero tampoco favorecieron a la Iglesia católica.

Por su parte la Constitución de 1793 no reconoció la libertad de pensamiento, sino la instrumental de manifestarlo por medio de prensa o por cualquier otro medio. Mientras que la Constitución de 1795 no proclamó en su prolija declaración ni la libertad de pensamiento ni la de imprenta, pero sí la de culto, aunque relegándola al artículo 354. 
e) Propiedad

Con todas sus peculiaridades, la revolución liberal española era también burguesa y la propiedad estaba en el centro de sus preocupaciones ${ }^{79}$. Sin la prosopopeya de la Declaración francesa de $1789^{80}$, la Constitución de 1812 la menciona en el tantas veces citado artículo 4 junto con la libertad civil y los demás derechos legítimos. Así que la propiedad es el único derecho concreto ${ }^{81}$ que este precepto reconoce. Otros la mencionan perfilándola, así el artículo 173 cuando se incluye en la fórmula de juramento del Rey el inciso «... que no tomaré a nadie su propiedad. « La mención en la fórmula de juramento, además de la significación simbólica, envuelve el ejercicio del poder ejecutivo atribuido al Rey, y concluye en qué actos contrarios al juramento son inválidos. Además de lo anterior, el artículo 304 proscribe la «pena de confiscación de bienes» e identifica así un contenido específico del derecho de propiedad: el de no ser sometido a pena de confiscación que se opone tanto a los tribunales como al legislador, pues este último no podía contemplarla en sus leyes. Por último, el artículo 294 dispone que: «sólo se hará embargo de bienes cuando se proceda por delitos que lleven consigo responsabilidad pecuniaria, y en proporción a la cantidad a que ésta pueda extenderse».

Por lo demás, el largo artículo 172 que contiene «las restricciones de la autoridad del Rey» dispone en el décimo apartado que «no puede el rey tomar la propiedad de ningún particular ni corporación, ni turbarle en la posesión, uso y aprovechamiento de ella; y si en algún caso fuese necesario para un objeto de conocida utilidad común tomar la propiedad de un particular, no lo podrá hacer, sin que al mismo tiempo sea indemnizado y se le dé el buen cambio a bien vista de hombres buenos».

79 Que se trataba de la propiedad burguesa no cabe ninguna dudad, LORENTE, ob. cit., pág. 219, y FERNÁNDEZ SEGADO, ob. cit., págs. 69 y 70.

${ }^{80}$ Hay que recordar no sólo la escueta mención a la propiedad contenida en el artículo 2, sino el retórico artículo 17: «derecho inviolable y sagrado». Por su parte, la Constitución de 1791, en una de sus Disposiciones fundamentales alude a la inviolabilidad de la propiedad. También la proclaman como derechos del hombre el artículo 2 de la Constitución de 1793 y el 1 de la Carta de 1795 , que viene luego a definirla en su artículo 15 y completarlo con el artículo 357 que preludia el derecho de propiedad intelectual. De lado americano, la enmienda quinta de la Constitución de 1787 prohíbe la privación de la propiedad, y antes el artículo I de la Declaración de Virginia

${ }^{81}$ Así que la propiedad es desde los orígenes del constitucionalismo, según Antonio-Enrique PÉREZ LUÑO y Alfonso RODRÍGUEZ DE QUIÑONES, un «derecho innato, atributo esencial de la personalidad humana», en ALZAGA (dir.), ob. cit., Tomo III, 1996, págs. 499 y 500. 
Este precepto incluido entre los variadas restricciones de los poderes regios, define en puridad, como en un negativo, al contenido del derecho de propiedad, porque tras la primera prohibición impuesta (tomar la propiedad) se detallan otras proscripciones: «ni turbar en la posesión, uso y aprovechamiento de ella». Nadie puede ser privado de la propiedad, pero tampoco perturbado en el uso pacífico de ella. La mentalidad burguesa, subyacente al liberalismo político, tiene así cabal manifestación, sino de manera tan enfática como en el artículo 17 de la Declaración de 1789, al menos aportando suficiente garantía.

El resto de la previsión del artículo 172, apartado décimo, contiene la lógica excepción: se contempla la expropiación, como en los textos franceses ${ }^{82}$, sometido a dos cautelas: la «conocida utilidad común» y la «simultánea indemnización» que sea «un cambio a bien vista de hombres buenos». Falta la moderna invocación a la ley, pero destacan las apelaciones reforzadas a la utilidad común que ha de ser «conocida», es decir, debe entenderse como evidente o manifiesta, y el justiprecio que debe abonarse al tiempo que se priva del bien. Las garantías constitucionales concretas sirven como primeras reglas de protección de la propiedad que «leyes sabias y justas» habrán de completar. El código civil y el de comercio acabarían siendo los baluartes mayores del «terrible derecho», en cuyo contenido estaba, desde luego, la libertad de comercio ${ }^{83} \mathrm{y}$, en general, la libertad económica ${ }^{84}$.

\section{f) Derechos políticos}

Si el artículo 23 de la vigente Constitución española reconoce los derechos políticos: el de participación y el de acceso a cargo público, la Carta gaditana regula ambos tipos de participación aunque no de modo sistemático. El principio inspirador es en ambas Constituciones el mismo: puesto que la Nación española

82 Artículo 17 de la Declaración de 1789, Disposiciones fundamentales de la Constitución de 1791, artículo 19 de la de 1793, y artículo 358 de la Constitución de 1795. La quinta enmienda de la Constitución estadounidense prohíbe la expropiación salvo para uso público y con justa indemnización.

83 LORENTE, ob. cit., pág. 218. Según recuerda José María MARTÍNEZ VAL, el artículo 131.21 de la Constitución de 1812 encomendaba a las Cortes «promover y fomentar toda especie de industria y remover los obstáculos que la entorpezcan», «Artículo 33: Propiedad privada y herencia», en ALZAGA (dir.), Comentarios a las leyes políticas, EDERSA, Tomo III, 1983, pág. 647.

${ }^{84}$ SÁNCHEZ AGESTA considera el Decrteto de 8 de agosto de 1813 más importante que la propia Constitución; en ese Decreto se proclamaron de la manera más completa las libertades económicas, Historia..., ob. cit., págs. 85 y 86. 
es la reunión de todos los españoles, la soberanía nacional reside en el pueblo español, la participación política en sus proteicas manifestaciones se reserva a todos los españoles, sin otras limitaciones que las establecidas en la respectiva Constitución y las leyes. En verdad esta pauta democrática había sido establecida por los textos constitucionales franceses y asimismo por la práctica arraigada ya entonces en los Estados Unidos ${ }^{85}$. El modelo francés que se mantendrá hasta la ruptura formalizada por la Constitución de 1799, parte de la concepción roussoniana de la ley como expresión de la voluntad general y de la proclamación del derecho de todos a participar en su elaboración. En paralelo se reconoce el derecho de acceso a cargos y empleos públicos ${ }^{86}$. Se trata de la manifestación pristina de la igualdad proyectada aquí en las relaciones políticas que, si bien parte de la proclamación de la soberanía nacional, acaba identificándola con la popular o afirmándola sin tapujos ${ }^{87}$.

La moderna representación política, en la que el sujeto representado es la nación, quedaba plasmada con sumo rigor, con ruptura radical del viejo modelo estamental $^{88}$, que se desactiva, en el plano individual, con la unidad de fueros y de códigos, mientras que en los planos colectivo e institucional, al no haber ya estamentos separados, con la idea de una Nación que engloba a todos sin distinción, de suerte tal que lo que ha de representarse es la Nación, una e indivisible ${ }^{89}$, no a cada estamento separado. Es la población la que determina la representación, como dispone la Carta de Cádiz: un diputado en Cortes por cada 70.000 «almas». Para justificar la regulación, el Discurso Preliminar advierte que la vieja representación estamental, amen de ser difícil de organizar, no estaba verdaderamente regulada y era «puramente una costumbre».

${ }^{85}$ Pero también proclamado en el artículo VI de la Declaración de Virginia, de 12 de junio de 1776. Asimismo se trasluce en el comienzo de la Constitución de 1787: «Nosotros el pueblo de la Estados Unidos...»

${ }^{86}$ Artículos 6 de la Declaración de 1789, 4, 25 y 129 de la Constitución de 1793 y 6, 17 y 20 de la Carta de 1795.

${ }^{87}$ El artículo 1 del Título III, de la Constitución de 1791, proclama que la soberanía pertenece a la Nación, mientras que el artículo 25 de la Constitución de 1793 dispone que «reside en el pueblo» y el artículo 17 de la Carta de 1795 «en la universalidad de los ciudadanos». Cada una de estas constituciones manifiesta una inspiración más o menos democrática, concretada en la manera en la que se hace efectivo el ejercicio del sufragio.

${ }^{88}$ Como recuerda FERNÁNDEZ SEGADO, esta quiebra de la representación estamental se formaliza con el Decreto de la Regencia, de 20 de septiembre de 1810, que convoca a reunión de Cortes en un solo cuerpo, ob. cit., págs. 84 y ss. También Antonio FERNÁNDEZ GARCÍA, Las Cortes de Cádiz (1812) y Discurso Preliminar a la Constitución, Castalia, Madrid, 2002, págs. 34 y ss.

89 SÁNCHEZ AGESTA, Historia..., ob. cit., págs. 83 y 84. 
La concepción democrática de la Carta del 1812 identifica soberanía nacional con soberanía popular ${ }^{90}$ y concluía en el sufragio activo universal. Aunque no hubiera proclamación expresa del derecho semejante a la del citado artículo 23 de la Constitución de 1978, esa universalidad del sufragio activo en la base electoral ${ }^{91}$ se deducía del artículo 27 donde se disponía que los diputados de Cortes «representarán a la Nación» y serían «nombrados por los ciudadanos». Es verdad que este sufragio universal era indirecto ${ }^{92}$, porque sólo operaba en la elección de las juntas electorales de parroquia y en los sucesivos pasos (juntas de partido y de provincia) se reservaba a los que iban paulatinamente siendo seleccionados, hasta que sólo las juntas de provincia elegían a los diputados. Asimismo el artículo 313 disponía que los ciudadanos de cada pueblo elegirían a los electores que a su vez designarían al alcalde ${ }^{93}$.

La audaz democratización gaditana podría haberse atemperado con la introducción de una segunda cámara aristocrática, tan frecuente en aquel tiempo y en los sucesivos, o con limitaciones exorbitantes del sufragio pasivo. Ninguna de las dos cosas ocurre. No hay tal Cámara de próceres y ni siquiera en la única prevista se reserva un cupo para nombramiento regio o de extracción hereditaria. Queda así una cámara de entera elección popular mediante sufragio universal indirecto. Bien es cierto que el artículo 25, sexto, anticipaba que, a partir de 1830, los que entrasen de nuevo en el ejercicio de derechos de ciudadano habría de saber leer y escribir. Esto, consecuencia de la creación de escuelas de enseñanaza elemental en todos los pueblos de la Monarquía, hubiera permitido en esa fecha introducir un sufragio capacitario que excluyera de él a quienes no se hubieran beneficiado de las oportunidades que la extensión de la enseñanaza básica acarrearía.

Para el ejercicio del sufragio activo exige la Constitución en todos los casos tener al menos 25 años y ser ciudadano avecindado en el territorio de la parroquia respectiva (artículo 35). Idénticos requerimientos se exigen para ser elector parroquial (artículo 45). Sin embargo, para obtener credencial de elector de partido (artículo 75), además de los anteriores requisitos, se requiere hallarse «en el ejercicio de sus derechos», expresión incierta que no sabemos si llegó a tener consecuencias jurídicas. Por último, los artículos 91 y 92 fijan las condiciones requeridas para ser diputado: además de los 25 años consabidos, así como estar en

90 TORRES DEL MORAL la califica de democracia representativa, ob. cit., pág. 39.

${ }^{91}$ Cfr. TOMÁS VILLARROYA, ob.cit., pág. 20, y FERNÁNDEZ SEGADO, ob. cit., pág. 86, aunque como recuerda CLAVERO, con exclusión de la mujer, ob. cit., pág. 37, pero no de los españoles ultramarinos como establecieron los Decretos V y XXXI.

${ }^{92}$ Lo que atemperaba su universalidad, FERNÁNDEZ SEGADO, ob. cit., pág. 86.

93 En el caso de los pueblos, según los viejos fueros españoles, apunta el Discurso Preliminar. 
el ejercicio sus derechos, nacido en la provincia por la que se pretende ser elegido o habiendo estado avecindado en ella al menos siete años. A lo anterior, el artículo 22 añade la condición de «tener una renta anual proporcionada, procedente de bienes propios». Llegados a este punto contemplamos la excepción al principio democrático en la regulación de sufragio pasivo que se limita en beneficio de los propietarios (aristocracia y burguesía), con exclusión de las clases populares que podían ejercer su voto en el primer escalón electoral, pero quedaban fuera del acceso al cargo público representativo de diputado.

Esta imposición censitaria no se produce en la elección de alcaldes y regidores, puestos para los que se exige (artículo 317) los 25 años, cinco años al menos de residencia en el pueblo, remitiéndose después el precepto a la ley que habrá de concretar «las demás cualidades que han de tener estos empleados». Tampoco el artículo 23, cuando reserva a los ciudadanos la obtención de empleos municipales y su elección, introduce otros requisitos.

Para hacer más llamativa la excepción censitaria que reserva los puestos de diputado a los propietarios, debe resaltarse que en la regulación constitucional del acceso a cargo público no representativo no hay tal exclusión, así que un no propietario podía llegar en principio a la judicatura o al Consejo de Estado, o ser secretario de despacho. Va de suyo que tampoco, aunque la Constitución no lo estipulase expresamente, se requería pureza de sangre o pertenecer a la aristocracia. Esta igualación en el acceso a empleos públicos que tanto las declaraciones americanas como francesa resaltan, se omite en la Carta gaditana aunque se colija sin dificultad de su texto y fuera plasmada en otras decisiones de las Cortes constituyentes que acabaron con la sociedad estamental.

Así para ocupar una Secretaría de despacho, lo que hoy llamaríamos un ministerio, el artículo 223 requiere ser ciudadano en ejercicio de sus derechos pero no asi el ser mayor de 25 años, con exclusión de los extranjeros aunque ostentasen carta de naturaleza. Las mismas condiciones se reclaman (artículo 231) para ser miembro del Consejo de Estado. Para ser juez se exigía la mayoría de 25 años y haber nacido en territorio español.

Llama la atención, en los tres últimos casos señalados, la exigencia de ser español de nacimiento, lo que no se demanda para ser diputado, cargo que podía llegar al ocupar el de origen extranjero que hubiera recibido la carta de ciudadano. Todavía en algunos países, en especial iberoamericanos, determinados puestos están reservados a los nacidos en el país, lo que, como en la Carta de Cádiz, introduce diferencias entre unos ciudadanos y otros a la hora de acceder a ciertos puestos públicos.

La participación política habría culminado, amen de las señaladas limitaciones del sufragio activo, en una restricción del sufragio activo de carácter capaci- 
tario — a partir de 1830—y, según lo previsto en el artículo 25 constitucional, por las causas de suspensión de los derechos de ciudadano: interdicción judicial por incapacidad física o moral, estado de quebrado o deudor de caudales públicos, encontrarse en estado de sirviente doméstico o por no tener empleo, oficio o modo de vivir conocido. En resumen, la participación popular, tan generosamente recogida en la Constitución, se habría reducido y aún más de haber prosperado durante el trienio liberal el intento, frustrado, de asimilar a todo trabajador por cuenta ajena con la condición de sirviente doméstico mencionada en el artículo 25 citado.

\section{g) Instrucción pública}

En la senda de la ilustración ${ }^{94} \mathrm{y}$ de los preceptos constitucionales franceses ${ }^{95}$, tan orientada a cifrar los males sociales en la falta de instrucción, la Carta de Cádiz dedica a la instrucción pública todo el título $\mathrm{IX}^{96}$, para que ella sirva de cauce, tanto para enseñar la religión católica como para educar en los valores constitucionales, de ahí la publicación de los llamados catecismos constitucionales ${ }^{97}$.

El primero de los preceptos del citado título, el artículo 366, impone la creación en todos los pueblos de la Monarquía de «escuelas de primeras letras en las que se enseñará a los niños a leer, escribir y contar, y el catecismo de la religión católica, que comprenderá también una breve exposición de las obligaciones civiles». Este precepto se completa con otros del mismo título, como el artículo 368, que exige la aprobación de un «plan General de enseñanza» que será uniforme, «debiendo explicarse la Constitución política de la Monarquía en todas las universidades y establecimientos literarios, donde se enseñen las ciencias eclesiásticas y políticas».

94 Como subraya Alfonso FERNÁNDEZ MIRANDA, «Artículo 27: Enseñanza», en ALZAGA (dir.), Comentarios a la Constitución..., ob. cit., Tomo III, pág. 161.

95 Una de las Disposiciones fundamentales de la Constitución de 1791 ordena crear una instrucción pública común y gratuita de enseñanzas indispensables. También el artículo 22 de la Constitución de 1793 apuesta por la instrucción al alcance de todos los ciudadanos.

96 En este sentido, cfr. Pilar GARCÍA TRABAT, «Una aspiración liberal: la enseñanza para todos», en Juan CANO BUESO (ed.), Materiales para el estudio de la constitución de 1812, TecnosParlamento de Andalucía, Madrid, 1989, págs. 303 y ss. Hay que destacar que sólo la Constitución francesa de 1795 dedica un título completo, el X, a la instrucción pública.

${ }^{97}$ Para CLAVERO, las previsiones constitucionales sobre instrucción pública implican todo un «programa cultural», ob. cit., pág. 40. El propio Discurso Preliminar dedica un apartado a resaltar su importancia. 
De lo anterior no es difícil deducir un derecho reflejo a la instrucción bási$\mathrm{Ca}^{98}$. Puesto que ésta resulta obligatoria ya que todos los niños han de aprender a leer, escribir, contar, religión católica y rudimentos de las obligaciones civiles, nace un derecho paralelo a exigir del Estado esa educación básica que el mismo precepto detalla. Pero el derecho también se convierte en un deber, a juzgar por la previsto en el artículo 25 . sexto que condiciona para los que en 1830 «entren en el ejercicio de los derechos del ciudadano» a saber leer y escribir; un deber cuyo incumplimiento es sancionado con la privación de tales derechos.

Desde luego, no estaba en el ánimo de los constituyentes privar a la Iglesia católica de su tradicional papel en la enseñanza, pero queda clara una tendencia regalista a imponer, también a la educación impartida por la Iglesia, planes de estudios uniformes decididos por las Cortes (artículos 131, vigesimosegunda y 370). No se reconoce, como sí lo hace el artículo 8 de la Constitución francesa de 1795 , un derecho a crear «establecimientos particulares de educación», pero la no prohibición ilustra que la intención del constituyente gaditano no era privar a la Iglesia de los centros que regentaba.

\section{h) Legalidad penal}

A diferencia de las declaraciones francesas que tan prolijamente tratan el asunto, como reacción enérgica frente a una de las prácticas más inicuas del absolutismo ${ }^{99}$, la Carta gaditana no contiene proclamación del principio de legalidad penal que cabe empero inferir de lo establecido en otros preceptos de la Constitución. Por un lado, el Rey no puede (artículo 172, décima y undécima) privar ni de la libertad ni de la propiedad; sólo a los jueces corresponde y éstos únicamente pueden aplicar las leyes aprobadas por las Cortes (artículo 242, 246 entre otros). Así que sólo en la medida en que las leyes prescriban la privación de la libertad o de los bienes podrían los jueces decretarla.

En relación con lo anterior, el artículo 305 asegura que las penas así previstas no puedan sufrirlas sino las personas que cometieron la acción punible, así

98 Derecho que entiende proclamado JIMÉNEZ ASENSIO, ob. cit., pág. 52. Distinto parecer sostiene ROMERO, ob. cit., pág. 77.

99 El artículo 8 de la Declaración de 1789 comienza por ordenar la proporcionalidad de las penas («estricta y evidentemente necesarias») y del principio nulla poena sine lege; este último se recoge asimismo en el artículo 14 de la Constitución de 1793; o de la retroactividad de las leyes penales (artículo 14 de la Constitución de 1795) que presupone el principio de tipicidad. Por su parte, también la enmienda sexta de la Constitución estadounidense de 1787 exige la previa tipificación del delito; cfr. también el artículo VIII de la Declaración de Virginia. 
que no podían trascender «a la familia del que la sufre» ${ }^{100}$. Se plasma el principio de personalidad de las penas, hoy indiscutido, junto con la proscripción de la pena de infamia ${ }^{101}$.

\subsection{Derechos procesales}

Las garantías de la libertad personal comentadas operan asimismo como garantías procesales, por cuanto que la intervención judicial es el principal de los mecanismos para asegurar la legitimidad de la detención. De lo que se trata ahora es de examinar cuáles son las formalidades procesales que generaban verdaderos derechos — garantías — en favor de los justiciables, y que los jueces estaban obligados preservar ${ }^{102}$. El cuadro de garantías y la regulación de los procesos que la Constitución gaditana introduce se ponen al servicio de la libertad, como apunta el Discurso Preliminar que explica su abandono precisamente por el mal funcionamiento de los procesos. El objetivo, según el Discurso, es hacer que la justicia sea «efectiva, pronta e imparcial», apelando de nuevo a las viejas leyes que por malaventura se abandonaron.

La Constitución no proclamaba el derecho de acceso a los tribunales, pero se infiere del principio de jurisdicción y de exclusividad ${ }^{103}$. Además, sobre el desenvolvimiento de los procesos se proyectaba la igualdad de fueros ya analizada, de tal suerte que, sólo con la excepción de eclesiásticos y militares, las normas procesales serían las mismas para todos. Estas normas que las Cortes habían de aprobar y los jueces en régimen de exclusividad aplicar, sin interferencia regia, habían de respetar los principios y garantías precisados en la Constitución. Dos garantías que analizaremos se extienden a todo tipo de procesos y los restantes a las causas criminales.

En verdad, si comparamos las garantías procesales recogidas en la Carta gaditana con las declaraciones francesas o americanas, concluimos en la parquedad española. En efecto, todas las gaditanas se proclaman en las francesas, salvo el no

$100 \mathrm{Al}$ respecto, cfr. ROMERO, ob. cit., pág. 90.

101 SEGURA ORTEGA, ob. cit., págs. 35 y 36.

102 Un sucinto análisis de las garantías procesales lo ofrecen FERNÁNDEZ SEGADO, ob. cit., pág. 90 y JIMÉNEZ ASENSIO, ob. cit., págs. 51 y 52. Mucho más completo es el estudio de ROMERO, ob. cit., págs. 86 y ss. José ALMAGRO NOSETE cita los artículos 244, 247 y 300 de la Constitución gaditana como precedentes del artículo 24 de la Constitución española, «Artículo 24: Derecho procesal», en ALZAGA (dir.), Comentarios a las leyes políticas, ob. cit., Tomo III, pág. 19.

103 Así lo subraya ROMERO, ob. cit., pág. 96. 
poco importante derecho a no declarar contra uno mismo, pero en la española faltan la mención a la presunción de inocencia (artículos 9 de la Declaración de 1789, 13 de la Carta de 1793), a la asistencia letrada (artículo 9, Capítulo V de la Constitución de 1791), al principio non bis in ídem (artículos 9, Capítulo V, de la Carta de 1791, 253 de la de 1795 y quinta enmienda a la Constitución estadounidense de 1787). También faltan toda referencia normativa a los jurados ${ }^{104}$ que regulan las Constituciones francesas y la séptima enmienda a la Constitución de 1787. Tampoco encontramos en la Carta de Cádiz una generalizada imposición de la obligación de motivar las resoluciones judiciales que se halla en los textos franceses (artículos 5, del Capítulo V de la Constitución de 1791, 86 de la Constitución de 1793 y artículo 210 de la Carta de 1795).

a) Derecho a juez predeterminado por la ley

De las primeras, la contenida en el artículo 246 es capital; establece que «ningún español podrá ser juzgado en causas civiles y criminales por ninguna comisión, sino por el tribunal competente determinado con anterioridad por la ley».

Puesto que la planta judicial se organizaba mediante ley de Cortes y por el mismo medio se prescribía la competencia de cada órgano judicial de la Monarquía (artículo 224), quedaba desterrada la arbitrariedad, además de impedir, en virtud del principio de exclusividad (artículo 242), que otros entes se ocupasen de administrar justicia. El resultado es un derecho reflejo de la prohibición: el derecho a juez predeterminado por la ley, traducción del anglosajón derecho al juez natural. De la aplicación de esta garantía no puede haber dispensa ni de las Cortes ni del Rey, pues si tal sucediera, para bien o para mal del justiciable, se introducirían tratos discriminatorios. La igualdad ante la ley y la efectividad del principio de unidad de fuero suponen la predeterminación legal del juez competente.

b) Derecho a dirimir controversias mediante árbitros

El artículo 280 reconoce un «derecho de terminar sus diferencias por medio de jueces árbitros, elegidos por ambas partes». De tal derecho «no se podrá

104 El Discurso Preliminar sí se refería al jurado para ponderarlo y alabarlo como institución «saludable»y «admirable», para después remitir su futura creación y regulación a la voluntad de la Cortes 
privar a ningún español». El artículo 271 reconoce el valor ejecutivo de las resoluciones de los árbitros, si las partes «no se hubieran reservado el derecho de apelar», se entiende que a los tribunales.

Llama la atención la cercanía de la regulación gaditana con las francesas ${ }^{105}$, cuando reconoce a las partes el derecho de sustraerse, en las causas civiles, a la jurisdicción estatal para ventilar sus diferencias mediante árbitros. Se amplía el ámbito de la autonomía de la voluntad cuya esfera natural de proyección, la libertad contractual, se extiende a la resolución de los conflictos entre particulares con el concurso de árbitros. El Estado que ofrece sus servicios jurisdiccionales para resolver las disputas, no se opone a que las partes, si lo acuerdan, nombren árbitros y se sometan a su criterio.

c) Motivación de algunas decisiones judiciales

Las otras garantías procesales se recogen en el capítulo III, título V, relativo a la «Administración de justicia de lo criminal». La garantía de motivación de las decisiones judiciales sólo se contempla respecto de los autos que ordenan el ingreso en prisión del arrestado (artículo 293), así que en el texto gaditano no se dispone con carácter general la obligación de motivar las resoluciones judiciales, sin que tal exigencia pueda colegirse de la propia naturaleza de la función jurisdiccional, porque, si bien algún diputado sugirió la extensión de la obligatoriedad de motivar a todas las resoluciones judiciales, las Cortes ni siquiera la debatieron ${ }^{106}$. Se perdió la ocasión que sí aprovecharon las declaraciones francesas ${ }^{107}$.

En España, por tanto, se mantuvo así inalterado en este punto el viejo modelo de actuación judicial de estirpe castellana que se había extendido, bajo el reinado de Carlos III, a todos los dominios españoles ${ }^{108}$. Habría que esperar a 1855 para que con las leyes de enjuiciamiento se clausurara un devenir histórico, comenzado en 1829. Solo entonces se generalizó la obligatoriedad de motivar las decisiones judiciales ${ }^{109}$.

105 Artículo 5 del Capítulo V de la Constitución de 1791 y artículos 86 de la Carta de 1793 y 210 de la Constitución de 1795.

106 GARRIGA y LORENTE recuerdan la desatendida propuesta del diputado Cea, ob. cit., págs. 280 y 281.

107 Artículos 9, Capítulo V de la Constitución de 1791, artículo 96 de la Carta de 1793 y artículo 208 de la Constitución de 1795.

108 Ibid., págs. 261 y ss.

109 Ibid., págs. 289 y ss. 
Se perdió en Cádiz la ocasión de asegurar la vinculación del juez a la ley - lógica consecuencia del principio de división de poderes - con la imposición de la obligación de motivar ${ }^{110}$, porque sólo mediante la motivación puede comprobarse la efectiva vinculación del juez a la ley. Nos obstante lo anterior, el artículo 254 de la Constitución de 1812 disponía:

«Toda falta de observancia de las leyes que arreglan el proceso en lo civil y en lo criminal hace responsables personalmente a los jueces que la cometieren».

El Decreto CCXLIV, de 24 de marzo de 1813, de Reglas para que se haga efectiva la responsabilidad de los empleados públicos ${ }^{111}$ contenía disposiciones dedicadas a los jueces (el Capítulo I). A todo empleado público se le podía exigir responsabilidad, pero en lo que respecta a los jueces no se acertó a articular un procedimiento efectivo frente a interpretaciones erróneas ${ }^{112}$, en especial porque esas interpretaciones no eran explícitas en unos pronunciamientos judiciales que sólo expresaban el fallo.

De lo que se trataba era de hacer valer el juramento de fidelidad a la Constitución que debían prestar los empleados públicos, frente a una administración, judicial o no, sospechosa de $»$ infidencia» ${ }^{113}$. El Código penal de 1822 cerró el círculo normativo de esa general exigencia de responsabilidad, que eran en verdad la personal a la que se refería el artículo 254 de la Carta y, en consecuencia, no se ventilaba en los procedimientos posibles — recursos de nulidad ${ }^{114} \mathrm{o}$ el previsto en los artículo 372 y 373 de la Constitución - la pertinencia técnica de la interpretación.

d) Derecho a no declarar contra uno mismo

Por su parte, el artículo 291 viene, por reflejo, a reconocer el derecho a no declarar contra uno mismo; en efecto, dispone: «La declaración del arrestado será sin juramento que a nadie ha de tomarse en materias criminales sobre hecho propio». La modernidad del precepto, además sin paralelo en las declaraciones francesas de entonces aunque estuviera presente en las americanas ${ }^{115}$, es eviden-

110 Ibid., pág. 383.

111 Cfr. al respecto GARRIGA y LORENTE, ob. cit., págs. 308 y ss.

112 Ibid., pág. 287.

113 Ibid., pág. 27.

${ }^{114}$ Cfr. El Decreto CCXVI, de 23 de enero de 1813, Cómo debe conocer el supremo Tribunal de Justicia de los recursos de nulidad.

${ }_{115}$ Artículo VIII de la Declaración de Virginia y enmienda quinta de la Constitución de los Estados Unidos

(C) UNED. Revista de Derecho Político

N. ${ }^{\circ}$ 82, septiembre-diciembre 2011, págs. 145-192 
te y conecta con la prohibición de tormento, éste pretendía obtener la verdad de los hechos forzando la voluntad del acusado mediante la tortura. El artículo 291 cuenta con la natural inclinación de las personas a no contar de grado lo que les perjudica, así que la prohibición de tormento sería causa de esa natural inclinación, conformando un proceso criminal donde sea probable que el acusado no confiese la comisión del hecho delictivo. La tortura para obtenerla tenía por consiguiente que venir prohibida (artículo 303).

e) Derecho a un proceso público

Por último, el artículo 302 establecía que el proceso «será público en el modo y forma que determinen las leyes». De nuevo una regla procesal, la de la publicidad de los procesos criminales, genera el derecho a un proceso público, con proscripción de los abominables procesos secretos. Como también las sesiones de la Cortes debían ser públicas, como las de los procesos criminales, el poder legislativo y ius puniendi del Estado tenían que ejercerse con publicidad para contribuir así a la formación de la opinión pública. En esto la Constitución de Cádiz sigue la línea de los precedentes americanos (sexta enmienda) y francesas (artículo 9, capítulo V de la Constitución de 1791, artículo 96 de la de 1793 y 208 de la de 1795).

Menos interesante resulta la referencia del artículo 302 al «modo y forma que determinen las leyes». No se impone la sumisión a la ley en la instrucción de los procesos, creando un derecho reflejo al proceso debido, el mismo que con solemnidad declara la quinta enmienda a la Constitución americana de 1787. La disposición no sirve para conformar un funcionamiento previsible de los procesos judiciales que comienza con la predeterminación legal del juez y continuase con el sometimiento de éste a las formalidades procesales previstas en la ley, porque la invocación del precepto parece más bien abrir la puerta a hipotéticas limitaciones de la publicidad en los procesos y no tanto a consagrar un derecho al debido proceso que, en todo caso, se colegiría de la sumisión del juez a las leyes procesales aprobadas por las Cortes.

\section{EL DERECHO DE REPRESENTACIÓN COMO MECANISMO DE DEFENSA DE LA CONSTITUCIÓN Y DE GARANTÍA DE LOS DERECHOS}

La rúbrica del título X y último de la Carta de 1812 es: «De la observancia de la Constitución y modo de proceder para hacer variaciones en ella». Aunque 
con timidez y sin que se dispongan mecanismos eficaces, el texto constitucional demuestra interés por la efectividad de lo previsto en él. Bien es cierto que no hallamos en la Constitución procedimiento alguno de defensa jurisdiccional de su supremacía, pero pretenderlo sería ilusorio si recordamos que sólo muy tardíamente en Europa se introducen mecanismos de este tenor. Pero están presentes en la Carta los dos grandes mecanismos de la defensa constitucional: la rigidez y la preservación de lo dispuesto en ella. Por lo que atañe a la primera, la Carta de Cádiz se defiende imponiendo un procedimiento para su reforma tan rígido que, cuando ésta se planteó, fue omitido para aprobar la nueva Constitución de 1837.

A pesar de que cualquier constituyente percibe que de nada sirve la rigidez si las infracciones a la constitución no son sancionadas o al menos desveladas y puestas ante la opinión pública, no era sencillo arbitrar un mecanismo concreto de defensa. Ni siquiera la Constitución estadounidense de 1787 formalizó el mecanismo que sólo se infirió jurisprudencialmente del principio de supremacía de la Constitución. En la experiencia francesa sólo la Constitución de 1799 atribuye al Senado conservador funciones de control de constitucionalidad, a requerimiento del gobierno o del tribunado; así conformó un control político, no jurisdiccional y limitado a los actos (artículo 21), no extendible, pues, al control de la leyes. Sobre estos pasos parece transitar la Carta gaditana, pero abriendo a los ciudadanos la posibilidad de ejercer el «derecho de representación».

Si una amplia libertad de expresión e imprenta permitía denunciar ante la opinión pública los ataques contra la Constitución, quedaba en el aire la posible sanción de las «infracciones a la Constitución», como las denomina el artículo 372. En este punto la regulación es insuficiente, pues sólo se dedican dos preceptos. El primero, artículo 372, obliga a las Cortes a considerar en sus primeras sesiones las infracciones que se hubieren cometido para poner remedio y «hacer efectiva la responsabilidad de los que hubieren contravenido a ella». No hay que olvidar que tanto el Rey, al subir al trono, como cualquier cargo público, civil o eclesiástico, habían de jurar, al tomar posesión, «guardar la Constitución» (artículo 374). Sin embargo, la única manera concreta que la Constitución prevé para hacer valer esa responsabilidad era el derecho de representación que a todo español reconocía el artículo 373 "para recabar la observancia de la Constitución», una suerte de actio popularis ${ }^{116}$, si bien no dirigida a los tribunales, sino «a las Cortes y al Rey» ${ }^{117}$.

116 Como explica Marta LORENTE SARIÑENA, Las infracciones a la Constitución de 1812, Centro de Estudios Constitucionales, Madrid, 1987, págs. 109 y ss.

117 SEGURA ORTEGA, ob. cit., págs. 39 y 40. 
Se actualizaba el viejo derecho de petición, que sin embargo la Constitución no proclama ${ }^{118}$, acotando su ámbito material ${ }^{119}$ y desfigurándolo con ello, pero manteniendo sus tradicionales destinatarios. Quedaba así configurado ni más ni menos que un derecho subjetivo y universal a reclamar la observancia de la Constitución ${ }^{120}$. Si esta era fuente de la voluntad de la Nación, reunión de todos los españoles, cada uno de estos podría exigir que esa voluntad se respetase. El Discurso Preliminar aclara y pondera la facultad que a todos los ciudadanos se reconoce cuando apunta que el «uso de este derecho es el primero de todos en un Estado libre», es decir, erige a todos los ciudadanos en defensores de la Constitución.

La idea inspiradora parece acotada y con ella es coherente residenciar en las Cortes la facultad de poner remedio y hacer efectiva la responsabilidad de las contravenciones ya que las Cortes representaban a la Nación. Se configura una defensa política de la Constitución y en este punto parece inocuo el papel regio como receptor de las peticiones ciudadanas, pues sólo mediante el ejercicio de las facultades regias reservadas podría el titular de la Corona poner remedio a las infracciones de la Constitución. Eran, en consecuencia, las Cortes las llamadas a erigirse en defensoras de la Ley fundamental.

No se resuelven, sin embargo, las hipótesis de defensa de la Constitución que de inmediato se plantean ¿qué ocurre si la infracción la comete el Rey o las Cortes? El primer caso se discute dramáticamente en la Asamblea Nacional francesa que resuelve, a la postre, condenar a muerte a Luis XVI, y que en efecto acontece en España con la ilegítima derogación por parte de Fernando VII de la Constitución de 1812.

Respecto de la infracción constitucional cometida por las propias Cortes, ya mediante una ley o por otro medio, el sistema de Cádiz no tenía remedio, pues, aunque el ejercicio del derecho de representación no excluya a ningún órgano de la posible denuncia, en ese supuesto las Cortes eran juez de su propia causa, a menos que hubiera de entenderse que en este caso fuera el Rey el encargado de po-

118 A diferencia de las Constituciones francesas: artículos 32 de la Carta de 1793, y 364 de la Constitución de 1795. En ambos casos cualquier autoridad pública es potencial receptora de las peticiones, pero la Constitución de 1795 impone su carácter individual.

119 José María GARCÍA ESCUDERO y Asunción GARCÍA MARTÍNEZ destacan esta limitación material del derecho de petición a reclamar las infracciones de la Constitución, «Artículo 29: Derecho de petición», en ALZAGA (dir.), Comentarios a la Constitución..., ob. cit., Tomo III, pág. 374

120 Al respecto, FERNÁNDEZ SEGADO, ob. cit., pág. 90 y JIMÉNEZ ASENSIO, ob. cit., pág. 48. 
ner remedio. La consecuencia fue que el procedimiento acabó sirviendo tanto como defensa de la Constitución, como, sobre todo, de defensa de la ley ${ }^{121}$, lo que vino confirmado por los Decretos de las Cortes. Sirvió, pues, para asegurar la división de poderes, de tal suerte que ni la rama ejecutiva ni la judicial desconocieran las leyes.

Lo cierto es que la Comisión de casos de responsabilidad por infracción de la Constitución tuvo muchísimo trabajo ${ }^{122}$, tanto en el primer período de vigencia de la Carta como en el trienio liberal. Muchos de los casos planteados tenía por objeto la supuesta vulneración de derechos y libertades, incluidas las contempladas en el artículo $4^{123}$. Ello convertía el ejercicio del derecho de representación en una suerte de amparo y como tal lo entendieron sus titulares que lo usaron con cierta profusión.

El mecanismo, apenas esbozado por los artículos 372 y 373 de la Constitución gaditana, se desarrolló en el Reglamento interno de la Cortes y, tras el proyecto non nato de 1813, fraguó en la Ley de 17 de abril de 1821 que establecía:

«Los delincuentes contra la Constitución podrán ser acusados ante los jueces y tribunales competentes por todo español a quien la ley no prohíba este derecho; y cualquiera puede representar contra los infractores al Rey que las hará examinar o juzgar por quien corresponda o directamente a las Cortes conforme al artículo 373 de la misma Constitución».

Sin demérito del papel de las Cortes, entraban en juego los tribunales para aliviarlas de la tarea que ya se sabía ingente y que resultaba de abrir una vía de queja a todos los ciudadanos. A la postre la facultad conferida a las Cortes consentía su constitución en una suerte de órgano jurisdiccional ${ }^{124}$, pero que en realidad configuraba un sistema de defensa de la Constitución de corte político, por mucho que la ley de desarrollo judicializara el sistema dando entrada en él a los jueces, como en cierto modo había ya acometido el Decreto CCXLIV, de 24 de marzo de 1813, que establecía los mecanismos judiciales de exigencia de la responsabilidad de los empleados públicos.

121 Así lo apuntan GARRIGA y LORENTE, ob. cit., pág. 287. La impunidad del legislador también acontecía en el sistema ideado por la Constitución francesa de 1799, pues solo los «actos» eran susceptibles de control por parte del Senado conservador (artículo 21).

122 Como destaca ROMERO MORENO, ob. cit., pág. 98.

123 LORENTE SARIÑENA analiza pormenorizadamente la frecuencia y los motivos de las invocaciones de los derechos por esta vía, ob. cit., págs. 180 y ss.

124 Así lo apunta ROMERO MORENO, ob. cit., pág. 97 


\section{DEBERES CONSTITUCIONALES}

Lo que en la actualidad el Derecho constitucional denomina deberes, la Carta gaditana los llama obligaciones de todos los españoles ${ }^{125}$. No faltan en el texto de 1812 los deberes clásicos que toda ley fundamental suele disponer: el deber de someterse al orden jurídico, el deber tributario y el militar. Como se desprende de la literalidad de los artículos que vamos a analizar, los deberes constitucionales son universales, sin distinción alguna, el reverso de los derechos constitucionales, también universales. La igualdad lo es en derechos, pero asimismo en deberes. Hay nítida ruptura con la sociedad del antiguo régimen en la que los «derechos» de un estamento constituían en realidad privilegios, como las cargas anejas a la diferente condición de los sujetos que variaban según su pertenencia o tal o cual casta.

En este punto la Carta de Cádiz es tributaria de la Constitución francesa de 1795 que sistematiza los deberes. Bien es cierto que con anterioridad otras cartas francesas habían previsto algunos deberes, pero no sistemáticamente bajo esta rúbrica, y centrados en el deber tributario (artículos 13 de la Declaración de 1789 y 101 de la Constitución de 1793). A pesar de su presentación sistemática, el capítulo de los deberes de la Carta de 1795 no menciona el tributario que se relega al artículo 306 (Título XI, el dedicado a las finanzas). En rigor, la parte dedicada a los deberes sólo proclama dos concretos: el de observar las leyes y cumplir los mandatos legítimos de las autoridades (artículos 3 y 5 ) y el deber de servir en la defensa de la patria (artículo 9); el resto de los preceptos contienen exhortaciones en tono moralizante ${ }^{126}$ que luego copiará la Constitución de 1812. Destaca el kantiano artículo 2 que recoge los principios de actuación del hombre y del ciudadano: "No hagas a otro lo que no quieras que te hicieran a ti. Haz constantemente a los demás el bien que te gustaría recibir de ellos». En tono similar, las exhortaciones del artículo 4 a ser «buen hijo, buen padre, buen amigo, buen esposo» sin lo cual no se puede ser «buen ciudadano».

En la senda de la Constitución francesa de 1795 camina, pues, la Constitución de Cádiz. Así la primera de las obligaciones que la Carta de Cádiz establece (artículo 6) la del «amor a la patria» y la de «ser justos y benéficos». Siempre se citan esta disposiciones constitucionales cuyo cumplimiento resultaba imposible de comprobar. El Estado sólo puede en verdad imponer aquello que está dis-

125 JIMÉNEZ ASENSIO analiza sucíntamente estas obligaciones, ob. cit., pág. 52.

126 Santiago SÁNCHEZ GONZÁLEZ subraya esta «impronta moralizante del constitucionalismo primitivo», «Artículo 30: Defensa de España», en ALAZAGA (dir.), Comentarios a la Constitución..., ob. cit., Tomo III, pág. 386. 
puesto a sancionar, y en este sentido el artículo 6 es un invocación de índole moral que rebasa los límites de la juridicidad y que, grato de leer, no demuestra sino una gran ingenuidad ${ }^{127}$.

El deber de sometimiento a los mandatos de los poderes legítimos viene dispuesto en el artículo 7 de la Constitución de 1812 del siguiente modo: «Todo español está obligado a ser fiel a la Constitución, obedecer las leyes y respetar las autoridades establecidas». Podría objetarse que la fórmula, al imponer un deber de fidelidad a la Constitución, violentaría la libertad ideológica y de imprenta que ella misma reconoce, en la medida en la que excluiría opiniones disconformes con lo previsto en la Ley fundamental que, por lo demás, prevé los mecanismos para su reforma. La fidelidad equivaldría, pues, no a conformidad sino a sumisión, tal y como prevé el artículo 9.1 de la Constitución de 1978.

El artículo 8 estipula el deber tributario: «También está obligado todo español, sin distinción alguna, a contribuir en proporción de sus haberes para los gastos del Estado». Este precepto viene completado por su casi gemelo del artículo 339, incluido en el título VII («De las contribuciones») y que reza así: «Las contribuciones se repartirán entre todos los españoles con proporción a sus facultades, sin excepción y privilegio alguno».

Los preceptos citados no pueden ser más rotundos cuando afirman el principio de igualdad tributaria y el principio de progresividad. Sólo falta el principio de legalidad tributaria que, sin embargo, con facilidad se desprende de la interpretación sistemática de los artículos 131. decimotercera, que reserva a las Cortes el establecimiento de nuevas contribuciones e impuestos y que refuerzan los artículos 329 y siguientes, y en el artículo 172, octava que prohíbe al Rey «imponer por sí ni directa ni indirectamente contribuciones y hacer pedidos bajo cualquier nombre o para cualquier objeto que sea, sino siempre los han de decretar las Cortes».

Tampoco falta el deber militar (artículo 9): «Está asimismo obligado todo español a defender la patria con las armas, cuando sea llamado por la ley», a su vez reforzado por el artículo 361: «Ningún español podrá excusarse del servicio militar, cuando y en la forma que fuere llamado por la ley». Aquí está el origen, en España, del ejército nacional, nutrido, no de voluntarios, sino de ciudadanos que sin distinción alguna tiene la obligación de prestar el servicio militar. La ruptura con los anteriores ejércitos del antiguo régimen resulta también obvia, en la estela de la práctica revolucionaria francesa.

127 Así lo destaca SÁNCHEZ AGESTA, Historia..., ob. cit., pág. 67. Ramón SOLIS lo califica de utópico, «Cara y cruz. La primera Constitución española (Cádiz 1812-Cádiz 1823)», en Revista de Estudios Políticos, núm. 126, 1962, págs. 145 y ss. 


\section{SUSPENSIÓN DE DERECHOS}

Asunto delicado del Derecho constitucional es el de la suspensión de garantías o derechos. Si asegurar su eficacia es tarea principal de los poderes públicos, suspenderlos, aun temporalmente, equivale a renuncia dramática y a confesión de que no siempre es posible su garantía y en ocasiones la supervivencia misma de Estado exige su suspensión. La anormalidad debe entonces preverse y darse cauce. El ejemplo clásico es el del dictador romano.

Pues bien, la Carta de Cádiz también aborda esta cuestión con los miras puestas en las constituciones francesas y en la experiencia inglesa de suspensión del hábeas corpus (1791-1808) en tiempos del premier Pitt ${ }^{128}$. De los debates gaditanos surgió un texto relativamente vago, menos preciso que los equivalentes franceses. Con todo, el artículo $308^{129}$ resultante y que cierra el capítulo II del título $\mathrm{V}$, aclaró algunos puntos o dicho de otro modo prevé limitaciones. La primera y determinante, que sólo las Cortes pueden decretar la suspensión de derechos. En segundo lugar, que no todos los derechos constitucionales pueden verse suspendidos sino exclusivamente los declarados en el capítulo II del título $\mathrm{V}$ que son las «formalidades prescritas para la arresto de delincuentes» y que hemos analizado en páginas anteriores. En tercer lugar, las Cortes han de precisar el tiempo de duración de la suspensión que no se limita en la Constitución ${ }^{130}$, así como determinar si afecta a todo o sólo a parte del territorio. En cuarto lugar, la Constitución invoca circunstancias extraordinarias que para la seguridad del Estado exijan decretar la suspensión, conformando un supuesto habilitante que, de no darse, impediría la suspensión. Bien es cierto que la expresión «circunstancias extraordinarias» es un rótulo vacío que Cortes podían llenar a su antojo ya que en el precepto no se hace mención, como en la Constitución francesa de 1799, a casos concretos. Habilitación semejante en manos del Rey habría sido intolerable y peligrosa, en poder de las Cortes esta facultad sería sólo empleada, según la defensa que del texto hizo Argüelles, con sumo cuidado, sólo si estuviera completamente justificada. Ahora bien, se abría la puerta a que la mayoría de las Cortes emplearan la facultad extraordinaria que le confería el artículo 308 para maniatar a la oposición. Semejante proceder hubiera tocado de muerte al régimen constitucional.

128 ROMERO, ob. cit., pág. 95.

129 Cuyo análisis completo realiza ROMERO, ob. cit., págs. 92 y ss.

130 El Discurso Preliminar destaca la importancia de la limitación temporal de la suspensión que debía establecer el legislador, y que de no existir abriría la puerta a la tiranía. 
Lo visto trata de la suspensión temporal y parcial de derechos del detenido, pero la Carta de Cádiz se refiere de modo incierto a otra suspensión calificable como individual y que se relaciona con el ejercicio de derechos políticos, limitables, a tenor de lo dispuesto en el artículo 25, para ciertos sujetos cuya condición se detalla. Se trata de una suspensión del ejercicio de derechos y no de una pérdida de su titularidad, así que superada la circunstancia en la que el sujeto se encontrase, recuperaría o adquiriría el pleno ejercicio de los derechos ${ }^{131}$. Las circunstancias $^{132}$, concretadas en el artículo 25 y sólo ellas (artículo 26) que llevaban aparejada la suspensión son: interdicción judicial por incapacidad física o moral, por estado de deudor quebrado o de deudor de los caudales públicos, por el estado de sirviente doméstico, por no tener empleo, oficio o modo de vivir conocido o por hallarse procesado criminalmente. Además el apartado sexto del artículo 25 introduce un criterio capacitario pues dispone que a partir de 1830 «deberán saber leer y escribir los que de nuevo entren en el ejercicio de los derechos de ciudadano». Esta limitación del ejercicio de sus derechos de modo indirecto convierte en deber el derecho reflejo a la instrucción. Se colegía del artículo 366 constitucional que, como explicamos, disponía la creación de escuelas de primeras letras en todos los pueblos de la Monarquía. En 1830 todos los nuevos ciudadanos habrían estado en condiciones de haber logrado esa mínima instrucción que el artículo 25, sexto exige.

Entre las otras causas de suspensión aquéllas en las que hay una intervención judicial son menos graves que las muy discutibles de dedicarse al servicio doméstico ${ }^{133}$ o no tener oficio o modo de vida conocido. Ninguna de ellas sería desde la perspectiva actual merecedora de la suspensión de derechos prevista en el precepto gaditano. Ahora bien, en los cánones de la época, la exclusión estaría justificada y no afectaría a tantos ciudadanos como el muy generalizado después sufragio censitario.

131 Parece introducirse una distinción entre español y ciudadano, reservándose para éste los derechos políticos, CLAVERO, ob. cit., pág. 44.

132 Todos ellos apuntados en las Constituciones francesas y en especial en la de 1795 (Título II, artículo 13). Porque la de 1791 no previó esta cuestión y la de 1793 sólo contemplaba los supuestos de encontrarse en estado de acusación o por sentencia en rebeldía (Del estado de los ciudadanos, artículo 6).

133 CLAVERO recuerda que durante el trienio liberal una iniciativa legislativa pretendió ampliar el concepto de sirviente a todo trabajo por cuenta ajena, ob. cit., pág. 44, como parecía disponer asimismo la más conservadora Constitución francesa de 1795 (Título II, artículo 13). 


\section{CONCLUSIÓN}

Como Francia, España carecía de práctica en la protección de la libertad, por mucho que el Discurso Preliminar encuentre precedentes en las viejas leyes de los reinos españoles que en todo caso habían sido de antiguo olvidadas. Justo lo contrario de la experiencia americana que plasmó con naturalidad su ya consolidado ejercicio de la libertad en las declaraciones de finales del siglo XVIII. Además el tiempo de vigencia de la Carta de Cádiz impidió consolidar un desarrollo normativo ${ }^{134}$ en los primeros años de su vigencia por la situación de guerra que se padecía y, en el trienio liberal, porque, si bien se aprobaron leyes importantes, tampoco hubo tiempo ni tranquilidad para juzgar la efectividad de los derechos proclamados.

No puede, desde luego, negarse la voluntad de las Cortes que incluso antes de aprobar la Constitución, dictaron varios decretos que anticipaban la protección de algunas libertades que a la postre acabaría brindando la Constitución. Así los decretos preconstitucionales aboliendo el tormento, estableciendo la unidad de fuero, la igualdad entre peninsulares y ultramarinos, la supresión de los señoríos o el que impulsó libertad de imprenta que tanto favoreció la discusión libre de las ideas en el proceso constituyente.

Las Cortes no se plantearon ni en consecuencia acometieron la aprobación de una previa declaración de derechos, al contrario que sus equivalentes americanos o franceses; no creyeron necesaria tal empresa y prefirieron subsumir la declaración en la misma Constitución, al modo de lo que acontece con las constituciones contemporáneas. Así procedió la comisión de Constitución que presentó un proyecto que ofrecía un esquema de declaración, en lo que tocaba a los derechos principales, casi idéntico al de la Constitución francesa de 1795: reconocimiento de derechos y definición de cada uno de ellos. Desechado este punto del proyecto, se acabó aprobando el sintético artículo 4 que, con todo, es una verdadera proclamación, cuya referencia a «los demás derechos legítimos» acaso pudiera haberse interpretado como cláusula abierta y, por tanto, más generosa, de tal suerte que con ella hubieran podido encontrar protección constitucional derechos que no se reconocen expresamente, un poco al estilo de la enmienda novena a la Constitución estadounidense de 1787 o de su gemelo español, artículo 29 de la Constitución española de 1869.

Lo que es innegable es la convicción, expresada en el Discurso Preliminar y reflejada en el texto constitucional, de proteger la libertad, no sólo mediante «le-

134 SEGURA ORTEGA, ob. cit., págs. 38 y 39. 
yes sabias y justas», sino, incluso, abriendo la vía (la del derecho de representación) que se convirtió en instrumento mediante el cual los ciudadanos, al poder denunciar las infracciones a la Constitución, reclamasen contra situaciones en las que sus libertades y derechos se veían menoscabados, una suerte de amparo sui generis.

La falta de una declaración sistemática no significa, como hemos tratado de demostrar que no haya una suficiente proclamación de derechos. Tanto en lo que atañe a los sustantivos como a los procesales, la Carta de Cádiz es parangonable a las declaraciones americanas y francesas. Su inspiración es sin duda liberal y este carácter no queda desfigurado por la invocación constante en el Discurso Preliminar a viejas leyes y usos de los reinos españoles que ni explicaban las innovaciones institucionales ni mucho menos su tratamiento de la libertad. El pretendido casticismo no impide, pues, que la asistemática declaración de derechos gaditana pueda adscribirse a ese tronco común de declaraciones americanas y francesas que teorizó Jellinek ${ }^{135}$.

Title:

RIGHT AND FREEDOMS IN THE CONSTITUTION OF 1812

\section{Summary:}

1. A Constitution without declaration but that proclaims rights and guarantees. 2. Ownership of the rights. 3. The absence of an express proclamation of the equality before the law, but forecast of its main consequences: equality of rights, unit of law and unit of codes. 4. General proclamation of the civil freedom, the property and the other legitimate rights. 5. The declared specific rights. 5.1. Right nouns: a) personal freedom. b) Protection of integrity. c) Inviolability of the address. d) The paradoxical stranger: freedom of the press and proscription of the religious freedom. e) Property. f) Political rights. g) Public instruction. h) Penal legality. 5.2. Procedural rights: a) Right to judge predetermined by the law. b) Right to dissolve controversies by means of referees. c) Motivation of some judicial resolutions. d) Right not to declare against one same one. e) Right to a public process. 6 . The right of representation like mechanism of defense of the Constitution and guarantee of the rights. 7. Constitutional duties. 8. Suspension of rights. 9. Conclusion.

135 George JELLINEK, La déclaration des droits de l'homme et du citoyen, Albert Fontemoing, Editeur, Paris, 1902. 


\title{
Resumen:
}

Aunque la constitución gaditana carece de una declaración de derechos o de un título en el que éstos se encuentren reunidos y sistematizados, los recoge, en cantidad apreciable y dispersos por todo el articulado. Se analizan los derechos expresamente declarados, así como algunas de las garantías que los revestían. Finalmente,, se estudia el sustituto del derecho de representación, esto es, de presentación de quejas y reclamaciones por vulneración de la Constitución, los deberes constitucionales y el régimen de suspensión de los derechos.

\begin{abstract}
:
Although Constitution of Cadiz lacks a declaration of rights or of a title in which these are reunited and systematized, it gathers them, in appreciable amount and dispersed by all the articulated one. The declared rights, as well as some of the guarantees are analyzed specifically that had them. Finally, the substitute of the representation right studies, this is, of presentation of complaints and claims by infringement of the Constitution, the constitutional duties and the regime of suspension of the rights.
\end{abstract}

\section{Palabras clave:}

Declaración de derechos, garantías, igualdad ante la ley, fuero, codificación, representación, deberes constitucionales, legalidad penal.

\section{Key words:}

Bill of rights, guarantees, equality before the law, jurisdiction, encoding, representation, duties constitutional, legality. 